\title{
บUsisersily
}

\section{Building-Integrated Photovoltaic/Thermal (BIPVT): LCA of a façade-integrated prototype and issues about human health, ecosystems, resources}

\author{
Lamnatou, C., Smyth, M., \& Chemisana, D. (2019). Building-Integrated Photovoltaic/Thermal (BIPVT): LCA of a \\ façade-integrated prototype and issues about human health, ecosystems, resources. Science of the Total \\ Environment, 660, 1576-1592. https://doi.org/10.1016/j.scitotenv.2018.12.461
}

Link to publication record in Ulster University Research Portal

\section{Published in:}

Science of the Total Environment

Publication Status:

Published (in print/issue): 10/04/2019

DOI:

10.1016/j.scitotenv.2018.12.461

\section{Document Version}

Author Accepted version

\section{General rights}

Copyright for the publications made accessible via Ulster University's Research Portal is retained by the author(s) and / or other copyright owners and it is a condition of accessing these publications that users recognise and abide by the legal requirements associated with these rights.

\section{Take down policy}

The Research Portal is Ulster University's institutional repository that provides access to Ulster's research outputs. Every effort has been made to ensure that content in the Research Portal does not infringe any person's rights, or applicable UK laws. If you discover content in the Research Portal that you believe breaches copyright or violates any law, please contact pure-support@ulster.ac.uk. 


\section{Accepted Manuscript}

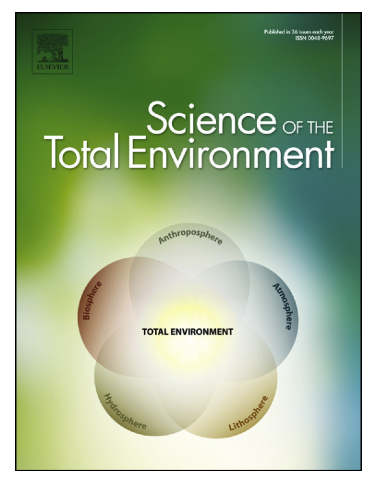

Chr. Lamnatou, M. Smyth, D. Chemisana

Building-Integrated Photovoltaic/Thermal (BIPVT): LCA of a
façade-integrated prototype and issues about human health, ecosystems, resources

PII:

S0048-9697(18)35357-9

DOI: https://doi.org/10.1016/j.scitotenv.2018.12.461

Reference: STOTEN 30295

To appear in:

Science of the Total Environment

Received date:

14 September 2018

Revised date:

12 December 2018

Accepted date:

30 December 2018

Please cite this article as: Chr. Lamnatou, M. Smyth, D. Chemisana, Building-Integrated Photovoltaic/Thermal (BIPVT): LCA of a façade-integrated prototype and issues about human health, ecosystems, resources. Stoten (2019), https://doi.org/10.1016/ j.scitotenv.2018.12.461

This is a PDF file of an unedited manuscript that has been accepted for publication. As a service to our customers we are providing this early version of the manuscript. The manuscript will undergo copyediting, typesetting, and review of the resulting proof before it is published in its final form. Please note that during the production process errors may be discovered which could affect the content, and all legal disclaimers that apply to the journal pertain. 


\section{Building-Integrated Photovoltaic/Thermal (BIPVT): LCA of a façade-integrated prototype and issues about Human health, Ecosystems, Resources}

Chr. Lamnatou ${ }^{1 *}$, M. Smyth ${ }^{2}$, D. Chemisana ${ }^{1}$

${ }^{1}$ Applied Physics Section of the Environmental Science Department, University of Lleida, Jaume II 69, 25001 Lleida, Spain

${ }^{2}$ Centre for Sustainable Technologies, Belfast School of Architecture and the Built Environment, Ulster University, Newtownabbey BT370QB, Northern Ireland, UK

*corresponding author: lamnatou@macs.udl.cat

\section{ABSTRACT}

Building-Integrated Photovoltaic/Thermal (BIPVT) technology offers multiple advantages; however, these types of installations include materials such as Photovoltaic (PV) cells and metals which considerably influence BIPVT environmental impact. Therefore, there is a need to evaluate BIPVT environmental profile, for instance by means of Life Cycle Assessment (LCA). In light of the issues mentioned above, the present article is an LCA study that assesses the environmental performance of a BIPVT prototype that has been developed and patented at the Ulster University (Belfast, UK). The investigation places emphasis on material manufacturing, based on Cumulative Energy Demand (CED), Global Warming Potential (GWP), ReCiPe, Ecological footprint and USEtox. The results show that according to all the adopted methods/environmental indicators and based on primary materials, the PV cells and the two vessels (steel) are the components with the three highest impacts. Scenarios which include recycling of steel, plastics and brass (landfill for the other materials has been assumed), based on CED, GWP 100a and ReCiPe endpoint, have been examined. It was found that steel recycling offers a considerable impact reduction, ranging from $47 \%$ to $85 \%$. Furthermore, the impact of the proposed BIPVT module per $\mathrm{m}^{2}$ of thermal absorber has been calculated. The results, based on primary materials, show 4.92 $\mathrm{GJ}_{\text {prim }} / \mathrm{m}^{2}$ and $0.34 \mathrm{t} \quad \mathrm{CO}_{2 . \mathrm{eq}} / \mathrm{m}^{2}$ (GWP 100a). In addition, according to 
USEtox/ecotoxicity, USEtox/human toxicity-non-cancer (scenario based on primary materials), the PV cells present the highest contributions to the total impact of the module: $55 \%$ in terms of ecotoxicity and $86 \%$ concerning human toxicity/non-cancer. A comparison with the literature is provided. Moreover, a separate section of the article is about factors which influence BIPVT environmental profile, discussing parameters such as the storage materials and the end-of-life management.

Keywords: Life Cycle Assessment (LCA); Building-Integrated Photovoltaic/Thermal (BIPVT); Greenhouse-Gas (GHG) emissions; Cumulative Energy Demand (CED); Human health, Ecosystems, Resources; Human toxicity, Ecotoxicity

1

\section{INTRODUCTION}

Photovoltaic/Thermal (PVT) modules (also known as hybrid PVT) convert solar radiation into electricity and heat, by combining Photovoltaic (PV) cells (for production of electricity) with solar thermal collectors (for production of thermal energy). The production of thermal energy is based on the following principle: There is utilisation (by means of a solar thermal unit) of the part of the absorbed solar radiation that is not converted into electricity by the PV cells. High temperatures reduce PV-cell efficiency whereas cooler PV cells produce higher electrical output. PVT modules can be designed to carry heat away from the PV cells and, therefore, an improvement in PV-cell efficiency can be achieved. Cooling can be done by means of different ways, for example by using water or air heat extraction. By taking into account the thermal

\footnotetext{
1 ABBREVIATIONS: ABS: Acrylonitrile Butadiene Styrene; BA: Building-Added; BA PVT: Building-Added Photovoltaic/Thermal; BI: Building-Integrated; BICPVT: Building-Integrated Concentrating Photovoltaic/Thermal; BIPV: Building-Integrated Photovoltaic; BIPVT: Building-Integrated Photovoltaic/Thermal; CED: Cumulative Energy Demand; CO $2 . e q$ : $\mathrm{CO}_{\text {2.equivalent }}$; $\mathrm{CTU}_{\mathrm{e}}$ : Comparative Toxic Unit for ecosystems; $\mathrm{CTU}_{\mathrm{h}}$ : Comparative Toxic Unit for humans; DALY: DisabilityAdjusted Life Years; EF: Ecological Footprint; EPBT: Energy Payback Time; ETFE: Ethylene Tetrafluoroethylene; Greenhouse-gas PBT: Payback time based on greenhouse-gas emissions; GWP 100a: Global warming potential with a time horizon of 100 years; GWP 20a: Global warming potential with a time horizon of 20 years; GWP 500a: Global warming potential with a time horizon of 500 years; GWP: Global Warming Potential; HDPE: High Density Polyethylene; ICS: Integrated Collector Storage; IPCC: Intergovernmental Panel on Climate Change; LCA: Life Cycle Assessment; $\mathrm{MJ}_{\text {prim: }} \mathrm{MJ}_{\text {primary }}$; PBT: Payback Time; PCM: Phase Change Material; PETG: Polyethylene Terephthalate Glycol; Pts: Points; PV: Photovoltaic; PVC: Polyvinyl Chloride; PVT: Photovoltaic/Thermal; ReCiPe PBT: Payback time based on ReCiPe method; ReCiPe: ReCiPe method; (species.yr): The loss of species over a certain area (during a certain time); USEtox: USEtox method
} 
properties of water and air, it can be said that water heat extraction is more effective (Tripanagnostopoulos et al., 2005).

Given the fact that PVT systems are particularly useful in the building sector, during the last years different PVT configurations appropriate for building applications have been developed. By having as a basis the type of building integration of a PVT module, in the literature two basic PVT categories can be found:

1) Building-Added PVT (BA PVT): The PVT modules are added to the building and they do not replace a construction component. In this case, the PVT modules are not incorporated into building architecture but are added as an additional Building-Added (BA) component.

2) Building-Integrated PVT (BIPVT): The PVT modules are part of the building structure and replace certain building elements (roof, cladding, façade, etc.) by means of an aesthetically pleasing way. In the literature different BIPVT configurations have been presented: Façade-integrated Fresnel-transmission PVT concentrator (Chemisana et al., 2016); BIPVT systems based on solar-cell tiles (Rajoria et al., 2016); Curtain-wall PVT collectors (Nemati et al., 2016), etc., verifying the usefulness of PVT in the frame of Building-Integrated (BI) applications.

Regarding environmental issues, PVT systems displace the use of conventional energy and, therefore, during the phase of usage, they provide energy savings, reduction in $\mathrm{CO}_{2}$ emissions and other environmental benefits (Tripanagnostopoulos et al., 2005; 2006). However, the manufacturing of the components of a PVT system includes environmental impacts which depend upon the type of the materials used. For this reason, Life Cycle Assessment (LCA) studies about PVT provide useful information, highlighting how these environmental impacts can be diminished (Lamnatou and Chemisana, 2017). 
In light of the issues mentioned above, in the literature, studies about PVT environmental profile by means of LCA have been presented. In the following paragraphs, certain references are cited.

Agrawal and Tiwari (2015) investigated glazed PVT/air collectors which can be integrated into a building (for space heating) or into a dryer (for crop drying). An Energy Payback Time (EPBT) of 1.8 years was found. Crawford et al. (2006) noted that the use of heat recovery in combination with a traditional BIPV configuration reduces the EPBT of the system. Kamthania and Tiwari (2014) studied a semi-transparent hybrid PVT double-pass façade based on silicon and non-silicon PV cells. Environmental issues such as carbon credits and $\mathrm{CO}_{2}$ mitigation were examined. Rajoria et al. (2016) investigated the environmental profile of PVT tiles, evaluating issues such as EPBT and $\mathrm{CO}_{2}$ mitigation. Chow and Ji (2012) conducted a work about PVT LCA: the studied BA PVT and BIPVT configurations showed EPBTs 2.8 and 3.8 years, respectively. The issue of building-material replacement, by means of a BI solar system, was discussed.

According to the review article by Lamnatou and Chemisana (2017):

1) BIPVT systems present multiple interesting characteristics with benefits from an energetic as well as from an environmental point of view.

2) In the building sector, there is a growing interest in BIPVT applications.

3) In the literature, there are few investigations about BIPVT environmental profile and most of these present findings about $\mathrm{CO}_{2}$ emissions and EPBT.

By taking into account the issues mentioned above (points 1-3) and, in general, the importance of PV systems and renewable energy sources in the frame of climate change mitigation (Owusu and Asumadu-Sarkodie, 2016), it can be seen that there is a need for 
more LCA studies about BIPVT, especially based on multiple life-cycle impact assessment methods, including indicators about human toxicity and ecotoxicity.

The present article examines the environmental performance of a patented BIPVT prototype that has been developed at the Ulster University (Belfast, UK). Emphasis has been placed on material manufacturing. Different methods and environmental indicators have been used (Cumulative Energy Demand (CED), Global Warming Potential (GWP), ReCiPe, Ecological Footprint (EF) and USEtox) in order to provide a complete picture about the profile of these types of modules, according to multiple environmental indicators, including human toxicity and ecotoxicity. Comparisons with the literature are also provided. A separate section with a critical discussion about factors that influence BIPVT environmental profile has been included. The goals of the present article are the following:

1) Presentation of multiple parameters that affect the environmental performance of different types of BIPVT modules, discussing key factors such as the working fluid and the storage materials.

2) Investigation of the environmental performance of a patented BIPVT module based on multiple environmental indicators and life-cycle impact assessment methods.

The structure of the present paper is the following:

- Part A: Critical factors about BIPVT environmental profile

\section{Presentation of different factors and discussion}

- Part B: LCA in terms of material manufacturing of the proposed BIPVT prototype Materials and methods - Results - Discussion-Comparisons with the literature - Future prospects 
By taking into account the fact that the studied PVT prototype includes materials that are commonly adopted in the frame of BIPVT (or BA PVT) applications, the findings of the present work can be useful for a wide range of PVT configurations.

\section{CRITICAL FACTORS ABOUT BIPVT ENVIRONMENTAL PROFILE: REPRESENTATIVE LITERATURE STUDIES AND DISCUSSION}

\subsection{Presentation of different factors and key parameters that influence BIPVT environmental performance}

BIPVT systems consist of different materials and certain of these materials can considerably influence the environmental profile of the whole system. The present subsection highlights, based on literature references, critical issues that affect BIPVT environmental performance. In Table 1, key parameters are presented.

Table 1. Key parameters related to BIPVT environmental profile.

\begin{tabular}{|c|c|c|}
\hline $\begin{array}{l}\text { Reference and } \\
\text { year of the study }\end{array}$ & Information - Description & $\begin{array}{l}\text { How these issues are related to } \\
\text { BIPVT environmental } \\
\text { performance }\end{array}$ \\
\hline $\begin{array}{l}\text { Krauter et al. } \\
\text { (1999) }\end{array}$ & $\begin{array}{l}\text { Thermal insulating PV façade with a } \\
\text { cooling system which includes a } \\
\text { propylene mat and a water pump }\end{array}$ & $\begin{array}{l}\text { These components influence the } \\
\text { environmental performance of } \\
\text { the system as well as the } \\
\text { interaction of the system with } \\
\text { building interior space }\end{array}$ \\
\hline $\begin{array}{l}\text { Chow et al. } \\
(2003)\end{array}$ & $\begin{array}{l}\text { Façade-integrated PVT for a } 30 \text {-storey } \\
\text { building }\end{array}$ & $\begin{array}{l}\text { Large-scale application; } \\
\text { Materials of the external façade: } \\
\text { Cement screed, concrete, } \\
\text { gypsum plaster }\end{array}$ \\
\hline $\begin{array}{l}\text { Chow et al. } \\
(2008)\end{array}$ & $\begin{array}{l}\text { Wall-integrated PVT system; Materials: } \\
\text { Aluminium alloy, glass fibre, bricks, etc. }\end{array}$ & $\begin{array}{l}\text { The materials of the whole } \\
\text { system influence BIPVT } \\
\text { environmental profile }\end{array}$ \\
\hline $\begin{array}{l}\text { Nayak and Tiwari } \\
(2008)\end{array}$ & PVT integrated into a greenhouse & $\begin{array}{l}\text { Energy savings in the frame of } \\
\text { greenhouses }\end{array}$ \\
\hline $\begin{array}{l}\text { Anderson et al. } \\
(2009)\end{array}$ & Roof-integrated PVT & $\begin{array}{l}\text { BIPVT that is integrated into a } \\
\text { roof above an enclosed air-filled } \\
\text { attic: In this case, the air space } \\
\text { plays the role of passive } \\
\text { insulation }\end{array}$ \\
\hline Chen et al. (2010) & $\begin{array}{l}\text { BIPVT combined with a ventilated } \\
\text { concrete slab }\end{array}$ & Low-energy solar house \\
\hline $\begin{array}{l}\text { Corbin and Zhai } \\
(2010)\end{array}$ & Roof-integrated PVT & $\begin{array}{l}\text { Potential for improved electrical } \\
\text { efficiency (in comparison to } \\
\text { façade-integrated PVT systems) }\end{array}$ \\
\hline
\end{tabular}


Kim and Kim $\quad$ BIPVT as an outer layer in order to

(2012) create a double-layer building envelope
The double-layer influences the thermal characteristics of the building and building energy loads

\begin{tabular}{|c|c|}
\hline Yin et al. (2013) & $\begin{array}{l}\text { Roof-integrated PVT for energy-efficient } \\
\text { buildings; The PV panels are embedded } \\
\text { between a transparent protective layer } \\
\text { and a functionally-graded-material layer } \\
\text { (materials: aluminium; High Density } \\
\text { Polyethylene (HDPE)) }\end{array}$ \\
\hline
\end{tabular}

\begin{tabular}{ll}
\hline $\begin{array}{l}\text { Ibrahim et al. } \\
(2014)\end{array}$ & $\begin{array}{l}\text { Primary-energy savings by means of a } \\
\text { water-based BIPVT }\end{array}$ \\
\hline Hu et al. (2014) & $\begin{array}{l}\text { Combination of BIPVT with Ethylene } \\
\text { Tetrafluoroethylene (ETFE) cushions }\end{array}$
\end{tabular}

Reduction of the primaryenergy consumption in the building sector

BIPVT: Production of energy and, at the same time, reduction in building energy consumption

The feasibility of the system in terms of its electricity production and its potential regarding solar-energy utilisation were verified

\begin{tabular}{|c|c|c|}
\hline $\begin{array}{l}\text { Roeleveld et al. } \\
(2015)\end{array}$ & $\begin{array}{l}\text { Numerical model: PV layer, air channel, } \\
\text { insulation, plywood layer }\end{array}$ & $\begin{array}{l}\text { The materials that are used for } \\
\text { the wall/roof, influence the } \\
\text { environmental profile of the } \\
\text { whole BIPVT system }\end{array}$ \\
\hline $\begin{array}{l}\text { Vuong et al. } \\
(2015)\end{array}$ & Thermal-fluidic relations & $\begin{array}{l}\text { Thermal-fluidic relations affect } \\
\text { BIPVT performance }\end{array}$ \\
\hline Li et al. (2015) & $\begin{array}{l}\text { PVT systems combined with corrugated } \\
\text { transpired solar collectors }\end{array}$ & BIPVT wall: Energy savings \\
\hline $\begin{array}{l}\text { Xiang and Gan } \\
(2015)\end{array}$ & $\begin{array}{l}\text { BIPVT in combination with Phase } \\
\text { Change Material (PCM) in order to } \\
\text { reduce PV temperature and store heat }\end{array}$ & $\begin{array}{l}\text { The material of the PCM } \\
\text { (hydrates salt) influences the } \\
\text { environmental performance of } \\
\text { the whole BIPVT system }\end{array}$ \\
\hline $\begin{array}{l}\text { Hailu et al. } \\
\text { (2015) }\end{array}$ & BIPVT combined with heat pump & $\begin{array}{l}\text { Energy-efficient system } \\
\text { for heating/cooling and hot- } \\
\text { water production }\end{array}$ \\
\hline Oliveira (2016) & $\begin{array}{l}\text { Compact building envelope: } \\
\text { Combination of PV panels with solar air } \\
\text { collectors and thermoelectric heat pumps }\end{array}$ & $\begin{array}{l}\text { Energy savings; Polygeneration } \\
\text { in buildings }\end{array}$ \\
\hline $\begin{array}{l}\text { Rounis et al. } \\
(2016)\end{array}$ & Multiple-inlet BIPVT system & $\begin{array}{l}\text { Increase in electrical and } \\
\text { thermal efficiency }\end{array}$ \\
\hline $\begin{array}{l}\text { Wang et al. } \\
(2016)\end{array}$ & Heat-pipe BIPVT system & $\begin{array}{l}\text { Low-carbon technology which } \\
\text { offers energy savings }\end{array}$ \\
\hline
\end{tabular}




\begin{tabular}{|c|c|c|}
\hline $\begin{array}{l}\text { Delisle and } \\
\text { Kummert (2016) }\end{array}$ & BIPVT for energy-efficient homes & Energy savings \\
\hline $\begin{array}{l}\text { Jouhara et al. } \\
\text { (2016) }\end{array}$ & Heat-pipe BIPVT as building envelope & $\begin{array}{l}\text { PVT collector as an energy- } \\
\text { active building material }\end{array}$ \\
\hline Luo et al. (2016) & BIPVT-wall system & $\begin{array}{l}\text { The BIPVT system replaces the } \\
\text { materials of a wall }\end{array}$ \\
\hline $\begin{array}{l}\text { Chen and Yin } \\
\text { (2016) }\end{array}$ & $\begin{array}{l}\text { BIPVT panel as a multi-functional } \\
\text { roofing system }\end{array}$ & $\begin{array}{l}\text { Replacement of the materials of } \\
\text { a roof }\end{array}$ \\
\hline & & -2 \\
\hline $\begin{array}{l}\text { Saadon et al. } \\
(2016)\end{array}$ & $\begin{array}{l}\text { BIPVT in a net-zero energy office } \\
\text { building }\end{array}$ & $\begin{array}{l}\text { Decrease in building cooling } \\
\text { needs }\end{array}$ \\
\hline Lin et al. (2016) & $\begin{array}{l}\text { PCM-enhanced building in combination } \\
\text { with a roof-integrated PVT and } \\
\text { ventilation }\end{array}$ & $\begin{array}{l}\text { Combination of a roof- } \\
\text { integrated PVT system with } \\
\text { other building components }\end{array}$ \\
\hline $\begin{array}{l}\text { Gholampour and } \\
\text { Ameri (2016) }\end{array}$ & $\begin{array}{l}\text { Wall-integrated PVT modules with } \\
\text { transpired collectors }\end{array}$ & $\begin{array}{l}\text { Transpired plate and air-channel } \\
\text { casing material: Steel }\end{array}$ \\
\hline $\begin{array}{l}\text { Khaki et al. } \\
(2017)\end{array}$ & $\begin{array}{l}\text { Glazed and un-glazed BIPVT } \\
\text { configurations }\end{array}$ & $\begin{array}{l}\text { Use of a glass cover over the PV } \\
\text { modules means: 1) use of an } \\
\text { additional component/material, } \\
\text { 2) increase in PVT thermal } \\
\text { performance, 3) decrease in } \\
\text { PVT electrical performance }\end{array}$ \\
\hline $\begin{array}{l}\text { Tripathy et al. } \\
\text { (2017) }\end{array}$ & $\begin{array}{l}\text { The influence of shadow effect on } \\
\text { BIPVT performance }\end{array}$ & $\begin{array}{l}\text { EPBT increases due to the } \\
\text { shadow effect }\end{array}$ \\
\hline $\begin{array}{l}\text { Gautam and } \\
\text { Andresen (2017) }\end{array}$ & $\begin{array}{l}\text { BIPVT vs. solar thermal and Building- } \\
\text { Integrated Photovoltaic (BIPV) } \\
\text { technologies: Investment price ratios; } \\
\text { Utility rates; Weather conditions }\end{array}$ & $\begin{array}{l}\text { In cold climates, BIPVT } \\
\text { technology can be competitive } \\
\text { (in comparison to traditional } \\
\text { technologies) but only in certain } \\
\text { cases (e.g. favourable electricity } \\
\text { to heat price ratio) }\end{array}$ \\
\hline $\begin{array}{l}\text { Tiwari and } \\
\text { Tiwari (2017) }\end{array}$ & $\begin{array}{l}\text { BIPVT for heating of slurry for a biogas } \\
\text { plant: Greenhouse-integrated } \\
\text { configuration }\end{array}$ & $\begin{array}{l}\text { BIPVT: Energy-savings in the } \\
\text { frame of agricultural } \\
\text { applications }\end{array}$ \\
\hline Deo et al. (2017) & $\begin{array}{l}\text { Semi-transparent BIPVT for roof- } \\
\text { integrated applications }\end{array}$ & $\begin{array}{l}\text { The influence of BIPVT on the } \\
\text { room temperature affects the } \\
\text { energy consumption of the } \\
\text { building e.g. in terms of air- } \\
\text { conditioning }\end{array}$ \\
\hline $\begin{array}{l}\text { Buonomano et al. } \\
\text { (2017) }\end{array}$ & $\begin{array}{l}\text { Combination of adsorption chiller with } \\
\text { BIPVT }\end{array}$ & $\begin{array}{l}\text { Primary-energy savings and } \\
\text { reduction in } \mathrm{CO}_{2} \text { emissions }\end{array}$ \\
\hline $\begin{array}{l}\text { Gupta et al. } \\
(2017)\end{array}$ & $\begin{array}{l}\text { Semi-transparent BIPVT: Daylight } \\
\text { strategies }\end{array}$ & Daylight savings \\
\hline $\begin{array}{l}\text { Asaee et al. } \\
(2017)\end{array}$ & BIPVT with heat pump & $\begin{array}{l}\text { Reduction in greenhouse-gas } \\
\text { emissions and energy savings }\end{array}$ \\
\hline $\begin{array}{l}\text { Abdolzadeh et al. } \\
(2017)\end{array}$ & $\begin{array}{l}\text { Combination of BIPVT with ETFE } \\
\text { cushions }\end{array}$ & $\begin{array}{l}\text { Sunlight for building spaces } \\
\text { (along with the production of }\end{array}$ \\
\hline
\end{tabular}


electricity)

\begin{tabular}{lll}
\hline Chialastri and & BIPVT for fenestration applications & Generation of thermal energy \\
Isaacson (2017) & & $\begin{array}{l}\text { and electricity, along with light } \\
\text { transmission and shading } \\
\text { control }\end{array}$
\end{tabular}

\begin{tabular}{lll}
\hline $\begin{array}{l}\text { Bigaila and } \\
\text { Athienitis (2017) }\end{array}$ & $\begin{array}{l}\text { Combination of BIPVT with heat pump } \\
\text { and PCM }\end{array}$ & Reduction in power demand \\
\hline $\begin{array}{l}\text { Assoa et al. } \\
(2017)\end{array}$ & $\begin{array}{l}\text { BIPVT for a drying system (drying of } \\
\text { fodder) }\end{array}$ & Energy savings in agriculture \\
\hline $\begin{array}{l}\text { Piratheepan and } \\
\text { Anderson (2017) }\end{array}$ & $\begin{array}{l}\text { Building-Integrated Concentrating } \\
\text { Photovoltaic/Thermal (BICPVT) for } \\
\text { façade-integrated applications }\end{array}$ & $\begin{array}{l}\text { BICPVT systems offer benefits } \\
\text { in the frame of net zero energy } \\
\text { buildings }\end{array}$ \\
\hline $\begin{array}{lll}\text { Wang et al. } \\
\text { (2017) }\end{array}$ & $\begin{array}{l}\text { The effect of frame shadow on BIPVT } \\
\text { performance }\end{array}$ & $\begin{array}{l}\text { Frame shadow reduces PV } \\
\text { efficiency }\end{array}$ \\
\hline $\begin{array}{l}\text { Debbarma et al. } \\
\text { (2017) }\end{array}$ & Weatherproofing; Insulation & $\begin{array}{l}\text { BIPVT replaces the materials } \\
\text { e.g. of a façade but, at the same } \\
\text { time, new materials (in order to } \\
\text { achieve weatherproofing and } \\
\text { insulation) are used }\end{array}$ \\
& & $\begin{array}{l}\text { Modelled system: Partial } \\
\text { covering of thermal/electrical } \\
\text { needs by using a radiant floor } \\
\text { and a heat pump for space } \\
\text { heating/cooling; An electrical } \\
\text { circuit that offers both direct } \\
\text { consumption and battery storage } \\
\text { was considered }\end{array}$ \\
\hline $\begin{array}{l}\text { Moreno et al. } \\
\text { (2018) }\end{array}$ & $\begin{array}{l}\text { BICPVT based on concentrators of } \\
\text { cylindrical shape }\end{array}$ &
\end{tabular}

\begin{tabular}{|c|c|c|}
\hline $\begin{array}{l}\text { Gupta and Tiwari } \\
(2018)\end{array}$ & $\begin{array}{l}\text { Heat capacity and water flow } \\
\text { (evaporative cooling) over semi- } \\
\text { transparent BIPVT modules }\end{array}$ & $\begin{array}{l}\text { The water that flows over the } \\
\text { PV modules offers an increase } \\
\text { in PV cell efficiency; This } \\
\text { means higher power output over } \\
\text { system lifespan and } \\
\text { improvement of certain } \\
\text { environmental indicators }\end{array}$ \\
\hline $\begin{array}{l}\text { Smyth et al. } \\
(2018)\end{array}$ & $\begin{array}{l}\text { Façade-integrated PVT with Integrated } \\
\text { Collector Storage (ICS) }\end{array}$ & $\begin{array}{l}\text { ICS offers collection of thermal } \\
\text { energy that can be directly used } \\
\text { in the building, and, at the same } \\
\text { time, it offers considerable } \\
\text { thermal insulation }\end{array}$ \\
\hline $\begin{array}{l}\text { Agathokleous et } \\
\text { al. (2018) }\end{array}$ & BIPVT with natural ventilation & $\begin{array}{l}\text { By adopting natural ventilation } \\
\text { there is no need for energy } \\
\text { inputs in order to power } \\
\text { mechanically driven fans }\end{array}$ \\
\hline $\begin{array}{l}\text { Ulloa et al. } \\
\text { (2018) }\end{array}$ & $\begin{array}{l}\text { Lightweight BIPVT modules for shelter } \\
\text { hangars }\end{array}$ & Energy savings \\
\hline $\begin{array}{l}\text { Shahsavar and } \\
\text { Rajabi (2018) }\end{array}$ & $\begin{array}{l}\text { Energy and enviro-economic analysis of } \\
\text { BIPVT configurations }\end{array}$ & $\begin{array}{l}\text { Reduction in } \mathrm{CO}_{2} \text { emissions and } \\
\text { energy savings }\end{array}$ \\
\hline
\end{tabular}




\begin{tabular}{lll}
\hline $\begin{array}{l}\text { Cappelletti et al. } \\
\text { (2018) }\end{array}$ & $\begin{array}{l}\text { BICPVT: 1) production of energy, 2) } \\
\text { shading device }\end{array}$ & $\begin{array}{l}\text { Control of the sunlight which } \\
\text { enters into the building; Shading } \\
\text { control }\end{array}$ \\
\hline
\end{tabular}

\subsection{Discussion about the factors presented in $\mathbf{2 . 1}$}

In the present subsection, a discussion based on Table 1 (including additional literature references) is presented.

Certain materials that are used as part of the total BIPVT system (materials for façades, walls, roofs, storage system, etc.) can considerably influence the environmental performance of the whole system, depending on the type of the material, its lifespan and the end-of-life management (use of primary and/or secondary materials, recycling, etc.) (Lamnatou and Chemisana, 2017).

There are some works which examine the effect of the PV-cell material, taking into account that, in certain cases, PV-cell production includes hazardous materials, depending on the type of the PV cell (Lamnatou and Chemisana, 2017).

The working fluid plays an important role. For instance, the literature shows that EPBT values (as well as Payback Times (PBTs) in terms of cost and $\mathrm{CO}_{2}$ emissions) are higher in the case of air-based PVT systems (in comparison to equivalent water-based PVT systems) because of the lower thermal efficiency of the air heat extraction (Tripanagnostopoulos et al., 2006).

The type of building integration (façade, roof, etc.) is another factor because it is associated with the efficiency of a solar system. A reduction in the amount of solar radiation that is received by the thermal absorber (and/or by the solar cells in the case of BI solar systems which include PV cells) negatively influences the output of the solar system and, therefore, its environmental profile. Moreover, tilt angles, orientations and latitude play an important role (Lamnatou and Chemisana, 2017). 
The adoption of natural ventilation, if this is possible in the frame of a certain design, simplifies the system and, at the same time, there is no need for mechanically driven fans (and, therefore, there is reduction in energy consumption for fans) (Agathokleous et al., 2018).

There are works that highlight the fact that BIPVT systems offer reduction in building energy consumption, decrease in $\mathrm{CO}_{2}$ emissions and they are useful towards net-zero energy buildings (Saadon et al., 2016).

Certain studies place emphasis on the shadow effect and how this phenomenon influences PV performance (Tripathy et al., 2017). Moreover, other works examine ways to increase PV efficiency: For instance, adoption of multiple inlets (Rounis et al., 2016).

Some investigations analyse BIPVT systems in the frame of multi-storey buildings. An example is the study by Chow et al. (2003) in which a large-scale BIPVT system was evaluated ( $260 \mathrm{~m}^{2} \mathrm{PV}$ wall; 30 -storey hotel building).

In certain cases, the materials of the storage system can remarkably influence the environmental profile of the whole BIPVT system. If a PV (or PVT) system includes batteries for electricity storage, the environmental impact of the batteries, depending on battery materials, influences the environmental profile of the whole system (Üçtuğ and Azapagic, 2018; Bazán et al., 2018). On the other hand, if the storage device includes large amounts of metals (Smyth et al., 2018) and there is use of primary materials (instead of secondary and recycled ones), this means a considerable environmental impact.

Given the fact that some solar systems include big quantities of metals, there are studies which propose the adoption of alternative materials. For instance, polymeric materials for PVT modules have been investigated by Cristofari et al. (2009). 
At this point it should be noted that there are few studies which examine the specific case of BICPVT systems. In general, BICPVT technology is promising from an environmental perspective since sunlight concentration allows the use of less PV-cell material. In addition, these systems (providing that there is cooling of the PV cells) offer higher PV output in comparison to simple PV configurations without sunlight concentration (Lamnatou and Chemisana, 2017).

BIPVT systems can be combined with ETFE material, for example with ETFE cushions. ETFE can be used as a lightweight cladding for buildings, offering flexible constructions, modern building designs and around 95\% light transmission. The combination of ETFE with BIPVT has been discussed, for example, in the review article by Lamnatou et al. (2018a).

Within the concept of utilising transparent materials, some authors propose the use of semi-transparent PV modules for the development of BIPVT systems which offer daylight savings (Gupta et al., 2017).

Another parameter is the weight of the PV panels for BI applications. Some authors propose the adoption of lightweight materials in order to reduce the total weight of a BI solar system (Martins et al., 2018).

Furthermore, there are studies which evaluate the combination of BIPVT with PCM components. This combination offers, for instance, reduction in PV-cell temperature and heat storage (Xiang and Gan, 2015). In the literature, BI solar thermal systems with fatty-acid PCM have been investigated (Motte et al., 2017; Lamnatou et al., 2018b, 2018c). The results showed that, in certain cases, PCM considerably influences the environmental profile of the whole BI solar system, depending on the environmental indicator. In the investigation by Lamnatou et al. (2018c) about LCA of a BI solar thermal system with fatty-acid PCM, it was found that according to USEtox 
human toxicity/cancer, USEtox ecotoxicity and ReCiPe endpoint with characterisation (species.yr), the fatty-acid PCM presents an impact remarkably higher in comparison to the other materials of the studied BI solar thermal system (Lamnatou et al., 2018c).

With respect to the electricity generation mix of a country, there are certain environmental indicators which show a high sensitivity to the composition of the electricity mix (Lamnatou et al., 2017).

Finally, it should be noted that some authors place emphasis on agricultural applications and propose the adoption of BIPVT systems, for instance, in the frame of greenhouses (Nayak and Tiwari, 2008).

In light of the issues mentioned above, the factors that influence the environmental performance of a BIPVT system can be classified into certain categories: Figure 1.

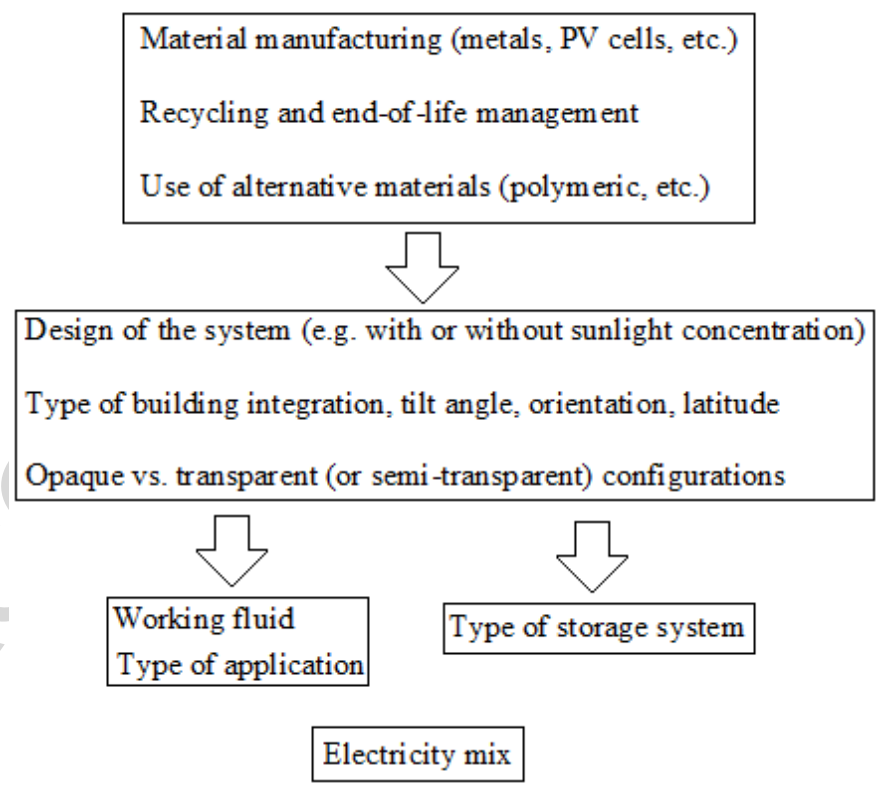

Figure 1. Factors that influence BIPVT environmental profile.

At this point it should be noted that given the fact that a BIPVT is a part of a building, its environmental performance affects the environmental profile of the whole building. This influence can be direct (e.g. the impact due to material manufacturing) or 
indirect (interaction of the BIPVT system with building interior space). For instance, daylight savings by means of a semi-transparent BIPVT configuration influence building energy consumption (Deo et al., 2017; Gupta et al., 2017).

\section{LCA: MATERIAL MANUFACTURING OF A BIPVT PROTOTYPE}

\subsection{Materials and methods of the present LCA study}

According to ISO 14040:2006 and ISO 14044:2006, goal and scope definition, lifecycle inventory, life-cycle impact assessment and interpretation, have been adopted.

\subsubsection{Type of life-cycle inventory modelling}

With respect to the type of the life-cycle inventory modelling:

i) The attributional modelling shows the potential environmental impacts that can be attributed to a system over its life cycle: upstream, downstream, end-of-life. Fact-based, measureable data of known (or knowable) uncertainty, including all the processes that have a significant contribution to the studied system are utilised. The system is modelled as it is or was (or is forecasted to be) (ILCD, 2010).

ii) The consequential modelling identifies the consequences that a decision in the foreground system has for other processes and systems of the economy and models the analysed system around these consequences. The consequential model does not represent the actual (or forecasted) specific or average supply-chain, but a hypothetic generic supply-chain which is prognostizised (ILCD, 2010).

In the light of the issues mentioned above, the present study is based on attributional modelling.

\subsubsection{Functional units and boundaries considered}

The present LCA is based on one PVT module (electricity production: $112 \mathrm{~W}$; thermal production: $400 \mathrm{~W}$; surface of the PV cells: $0.56 \mathrm{~m}^{2}$; surface of the thermal absorber: $1 \mathrm{~m}^{2}$ ). For the calculations of the impact, material manufacturing has been 
considered, taking into account all the materials of one PVT module. Moreover, certain results are presented per $\mathrm{m}^{2}$ of thermal absorber.

In the frame of the present LCA study, only the stages of material manufacturing (components/materials of one PVT module) and disposal have been taken into account. The stage of transportation of the PVT module from the factory to the building and from the building to the disposal site has not been considered since the present LCA evaluates only one PVT module and, therefore, the impact related to its transportation is expected to be very low.

\subsubsection{Technical characteristics of the studied PVT}

The studied PVT module (Figure 2) has been developed at the Ulster University, in the UK, and it has been patented by Smyth (2013). Figure 2 illustrates the prototype unit that is based on a patented thermal diode ICS vessel (elliptical profile; dimensions: $1 \mathrm{~m} \times 1 \mathrm{~m}$ and $150 \mathrm{~mm}$ deep). The vessel was made from a stainless-steel outer vessel (there is support by an exo-skeleton). The inner vessel serves as thermal storage and it has a similar elliptical profile. Its volume is 35.1 litres under no vacuum and 35.65 litres under vacuum. There is also a weathertight enclosure. Acrylonitrile Butadiene Styrene (ABS) material has been used for the sides and back. Moreover, there is insulating layer (outer casing). Clear (UV treated) Polyethylene Terephthalate Glycol (PETG) has been utilised for the aperture front. The proposed PVT module is appropriate for façadeintegrated applications. More analytically, it offers: 1) Decrease in the heat loss in the case of cool climate conditions and decrease in terms of the cooling loads in the case of warm climate conditions (by acting as an additional insulating element of the building), 2) Energy savings, 3) Reduction in carbon footprint. It should be noted that the proposed module can be adopted in the frame of a wide range of building structure typologies (new-build domestic, commercial buildings, etc.). 


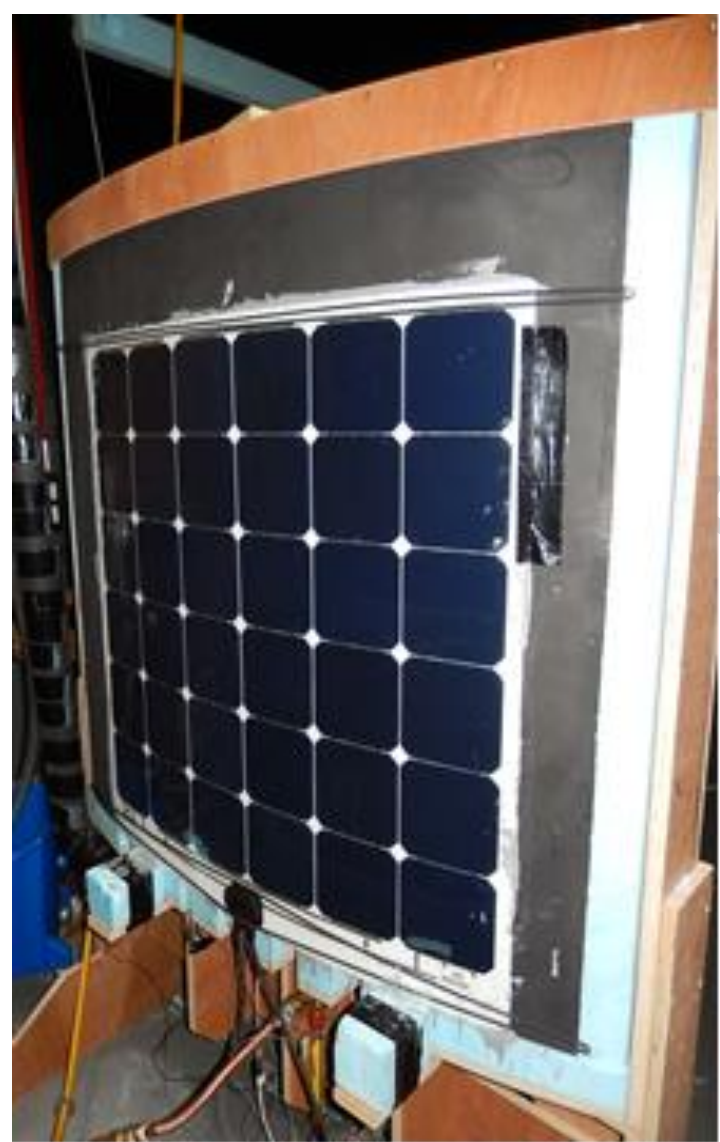

Figure 2. The BIPVT module that has been patented by Smyth (2013).

\subsubsection{Scenarios}

In certain cases, recycling of steel, plastics and brass has been included whereas, in other cases, the calculations are based on primary materials. The scenario «with recycling» has been examined because the proposed BIPVT module, and in general many types of PVT modules, consist of large amounts of metals. This means that these types of modules show high recycling potential. The scenario «without recycling» has been investigated so as to compare two extreme cases, with/without recycling, and verify the environmental advantages of recycling in the case of these types of modules. The two scenarios about recycling are related to the stage of disposal.

In terms of GWP time horizon, three scenarios have been evaluated: GWP 20a (based on a time horizon of 20 years), GWP 100a (based on a time horizon of 100 years), GWP 500a (based on a time horizon of 500 years). These different time horizons 
have been adopted in order to present a broad picture about GWP by taking into account that certain substances (associated with GWP) show a gradual decomposition and become inactive on a long-term basis. It should be noted that GWP 100a is the most commonly used (PRé, 2014). The three scenarios about GWP time horizons are related to the stage of material manufacturing.

\subsubsection{Sources of data and life-cycle inventory}

In Table 2, details about the components/materials of one PVT module are presented. The sources for the impact of the materials are SimaPro 8 and ecoinvent 3 . In subsection 3.1.6, more information about the sources mentioned above is given.

Table 2. Life-cycle inventory: One PVT module.

\begin{tabular}{ll}
\hline COMPONENTS/MATERIALS & $\begin{array}{l}\text { MASS } \\
\text { (kg per module) }\end{array}$ \\
\hline PV cells (mono-crystalline) & 1.70 \\
Outer vessel (steel) & 21.09 \\
Inner vessel (steel) & 12.64 \\
Casing (ABS) & 4.94 \\
Aperture casing (PETG) & 3.05 \\
Insulation (polystyrene) & 2.12 \\
Brackets (steel) & 1.41 \\
Pipework (HDPE) & 0.52 \\
Pipework (steel) & 0.36 \\
Fittings (steel) & 0.25 \\
Cables (Polyvinyl Chloride (PVC) and copper) & 0.10 \\
Bonding paste (polymer) & 0.10 \\
Gaskets (silicone) & 0.10 \\
Bolts (steel) & 0.05 \\
Screws (brass) & 0.02 \\
\hline
\end{tabular}

\subsubsection{Life-cycle impact assessment methods and environmental indicators}

The evaluation of the environmental profile of the proposed PVT module (Sources: SimaPro; ecoinvent) has been based on: 
1) Cumulative Energy Demand V1.08 / Cumulative energy demand

2) IPCC 2013 GWP 20a V1.00; IPCC 2013 GWP 100a V1.00; IPCC 2013 GWP 500a $\mathrm{V} 1.00$

3) ReCiPe Endpoint (H) V1.10 / Europe ReCiPe H/A (single-score)

4) ReCiPe Endpoint (H) V1.10 / Europe ReCiPe H/A (with characterisation)

5) ReCiPe Midpoint (H) V1.10 / Europe Recipe H (with characterisation)

6) Ecological footprint V1.01 / Ecological footprint (single-score)

7) USEtox (default) V1.03 / Europe 2004 (with characterisation)

In terms of the above mentioned methods, CED includes characterisation factors for the energy resources. IPCC 2013 lists the climate change factors of Intergovernmental Panel on Climate Change (IPCC) according to a timeframe of 20 , 100 and 500 years. ReCiPe includes midpoint and endpoint impact categories. EF is the sum of time integrated (direct and indirect) land occupation, in relation to nuclear energy use and $\mathrm{CO}_{2}$ emissions from the use of fossil energy. USEtox includes characterisation of human and eco-toxicological impacts (PRé, 2014).

Information about the sources mentioned above (SimaPro; ecoinvent), the lifecycle inventory (Table 2) and the impact of the materials is following presented:

- SimaPro is a software that contains several impact assessment methods that can be adopted in order to find impact-assessment results (PRé, 2014).

- Ecoinvent is a comprehensive and transparent database with multiple life-cycle inventory datasets (Source: ecoinvent).

- The final scores of the materials have been calculated by considering the impact of each material from SimaPro 8 and by using the database ecoinvent 3 . For the calculations, the impacts per $\mathrm{kg}$ of material (or per $\mathrm{m}^{2}$ in the case of the PV cells) have been utilised. 
- With respect to the geographic locations of the materials, for the PV cells, the steelbased components, the polymer bonding paste, the ABS casing, the PETG aperture casing, the polystyrene insulation, the silicon gaskets and the HDPE pipework, $\{$ RER $\}$ (Europe) option has been used. For the steel pipework, the steel brackets and the cables, $\{\mathrm{GLO}\}$ option has been adopted. GLO means global and includes activities that are valid for all countries in the world. For brass screws, $\{$ RoW $\}$ has been utilised. RoW represents the Rest-of-the-World (Source: Methodology of ecoinvent 3).

Based on the explanations presented above, in Figure 3, a schematic is illustrated.

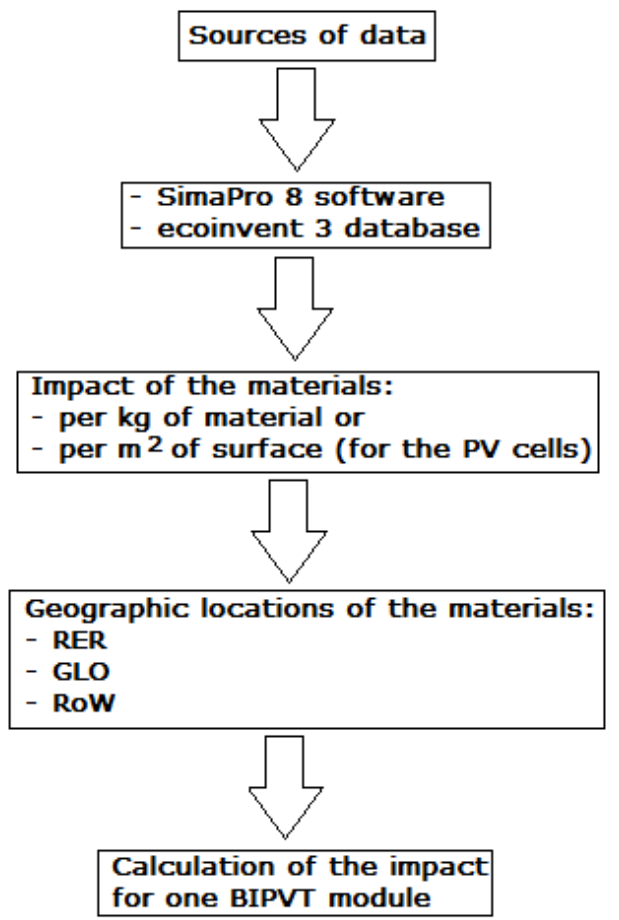

Figure 3. A schematic about the present LCA study. 


\subsection{Results and interpretation of the findings of the present LCA study}

\subsubsection{Phase of material manufacturing: One PVT module (primary materials)}

It should be clarified that subsection 3.2.1 presents results based on primary materials whereas in subsection 3.2.2 the effect of recycling is examined.

\section{Results based on CED}

In Table 3, CED values for each component/material of one PVT module are presented. From Table 3 it can be seen that the PV cells and the two vessels are the components with the highest CED, showing values ranging from 676.17 to 1985.69 $\mathrm{MJ}_{\text {prim. }}$ Regarding the casing (ABS), the aperture casing (PETG) and the insulation (polystyrene), these three components present values ranging from 224.43 to 486.67 $\mathrm{MJ}_{\text {prim. }}$ All the other components show values less than $86 \mathrm{MJ}_{\text {prim }}$ (each component/material). In addition, it can be noted that: 1) PV-cell CED is almost double in comparison to the outer-vessel CED, 2) Outer-vessel CED is almost double in comparison to the inner-vessel CED.

Table 3. CED: One PVT module.

\begin{tabular}{ll}
\hline COMPONENTS/MATERIALS & MJ Jrim \\
\hline PV cells (mono-crystalline) & 1985.69 \\
Outer vessel (steel) & 1128.20 \\
Inner vessel (steel) & 676.17 \\
Casing (ABS) & 486.67 \\
Aperture casing (PETG) & 231.47 \\
Insulation (polystyrene) & 224.43 \\
Brackets (steel) & 85.45 \\
Pipework (HDPE) & 39.73 \\
Pipework (steel) & 21.82 \\
Fittings (steel) & 13.37 \\
Cables (PVC and copper) & 8.46 \\
Bonding paste (polymer) & 6.74 \\
Gaskets (silicone) & 5.42 \\
Bolts (steel) & 2.67 \\
Screws (brass) & 1.45 \\
\hline
\end{tabular}




\section{Results based on GWP}

Figure 4 illustrates the contribution of each component/material to the total GWP (according to 20a, 100a and 500a) of one PVT module. From Figure 4 it can be seen that the PV cells and the two vessels present the highest GWP values, ranging from 52.33 to $145.97 \mathrm{~kg} \mathrm{CO}_{2 . \mathrm{eq}}$ (according to GWP 100a). From Figure 4, the effect of time horizon is also observed. The results based on the three time horizons show differences which range from 0.01 to $32.06 \mathrm{~kg} \mathrm{CO}_{2 . e q}$, depending on the scenario. Moreover, as was expected, the lower the time horizon the higher the GWP value.

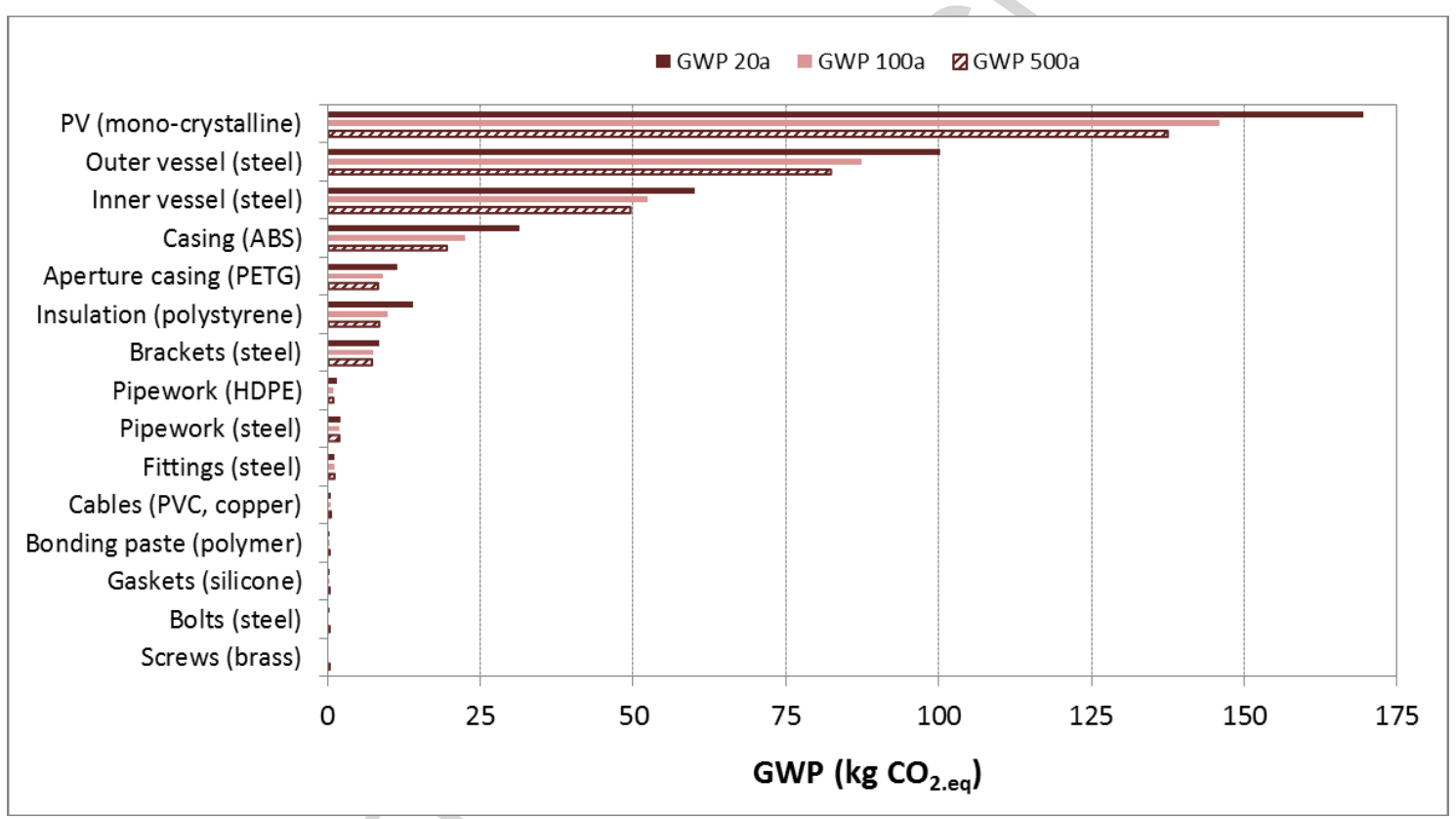

Figure 4. GWP: One PVT module. Results according to the time horizons 20a, 100a and 500a.

Results based on ReCiPe endpoint single-score

In Figure 5, the findings according to ReCiPe endpoint single-score are illustrated. By including all the endpoint categories (Human health, Ecosystems and Resources) (Figure 5), it can be noted that the PV cells and the two vessels present the highest values, ranging from 14 to 23 Points (Pts), whereas all the other components show scores less than 2.3 Pts (each component/material). Moreover, from Figure 5 it can be seen that, in general, the categories of Human health and Resources show considerably higher scores in comparison the category of Ecosystems. In the case of the 
PV cells and the two vessels, the differences between the categories of Human health and Resources and the category of Ecosystems are pronounced. Furthermore, it can be seen that the impact of the outer vessel in terms of the category of Resources is 3 times the impact of the PV cells in terms of this category.

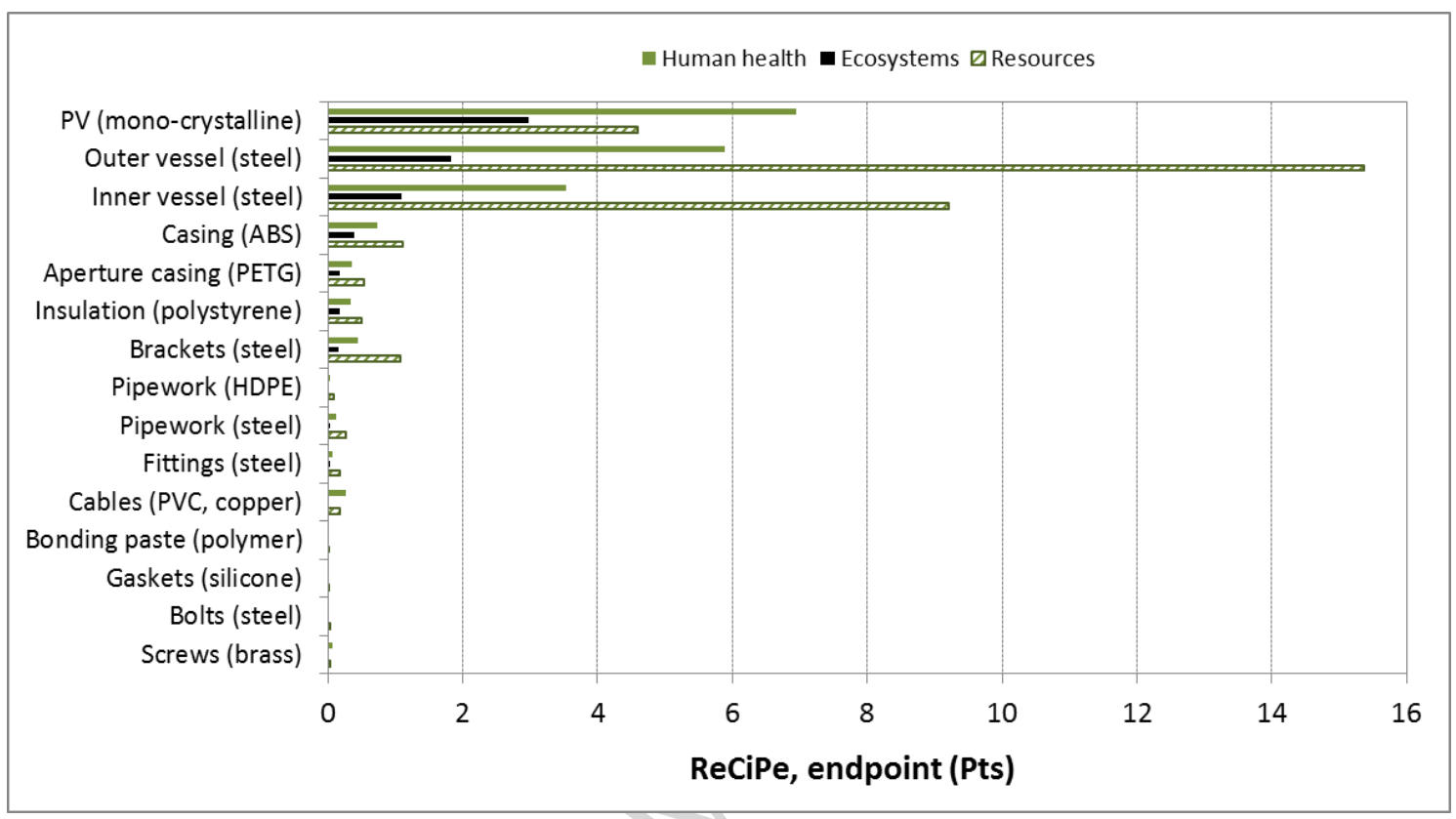

Figure 5. ReCiPe endpoint single-score: One PVT module. Results according to Human health, Ecosystems and Resources.

\section{Results based on ReCiPe endpoint with characterisation}

In Figure 6 the results based on ReCiPe endpoint with characterisation are illustrated. Figure 6a is based on Disability-Adjusted Life Years (DALY): Total impact for the categories of Climate change/human health, Ozone depletion, Human toxicity, Photochemical oxidant formation, Particulate matter formation and Ionising radiation. Figure $4 \mathrm{~b}$ is based on (species.yr): Total impact for the categories of Climate change/ecosystems, Terrestrial acidification, Freshwater eutrophication, Terrestrial ecotoxicity, Freshwater ecotoxicity, Marine ecotoxicity, Agricultural land occupation, Urban land occupation and Natural land transformation. Both, DALY and (species.yr), verify that the PV cells and the two vessels show the highest impacts, ranging from 1.8E-04 to 3.5E-04 DALY and from 4.9E-07 to 1.3E-06 (species.yr). Moreover, it can 
be noted that the PV cells are responsible for $37 \%$ of the total DALY score and $43 \%$ of the total (species.yr) score.

a)

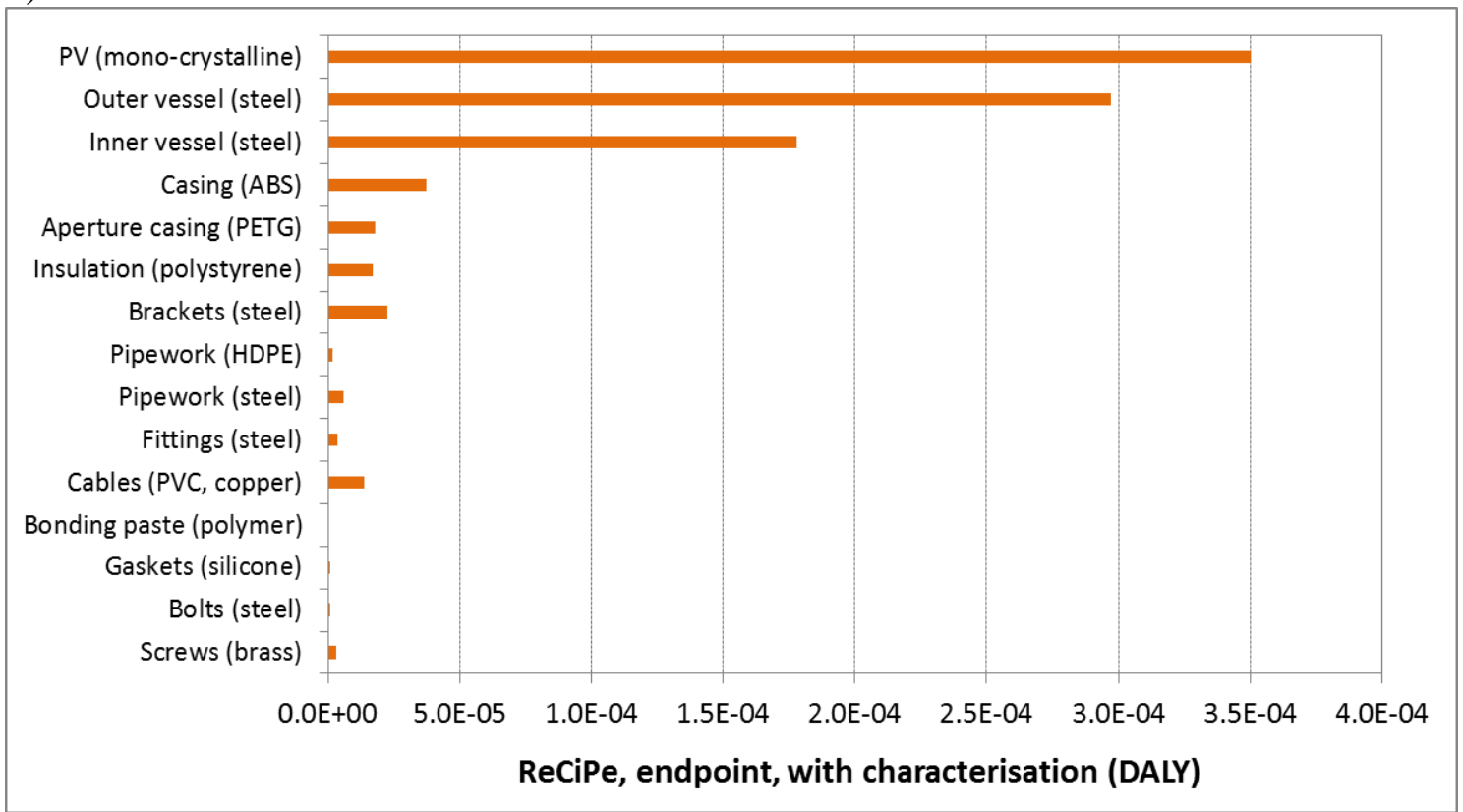

b)

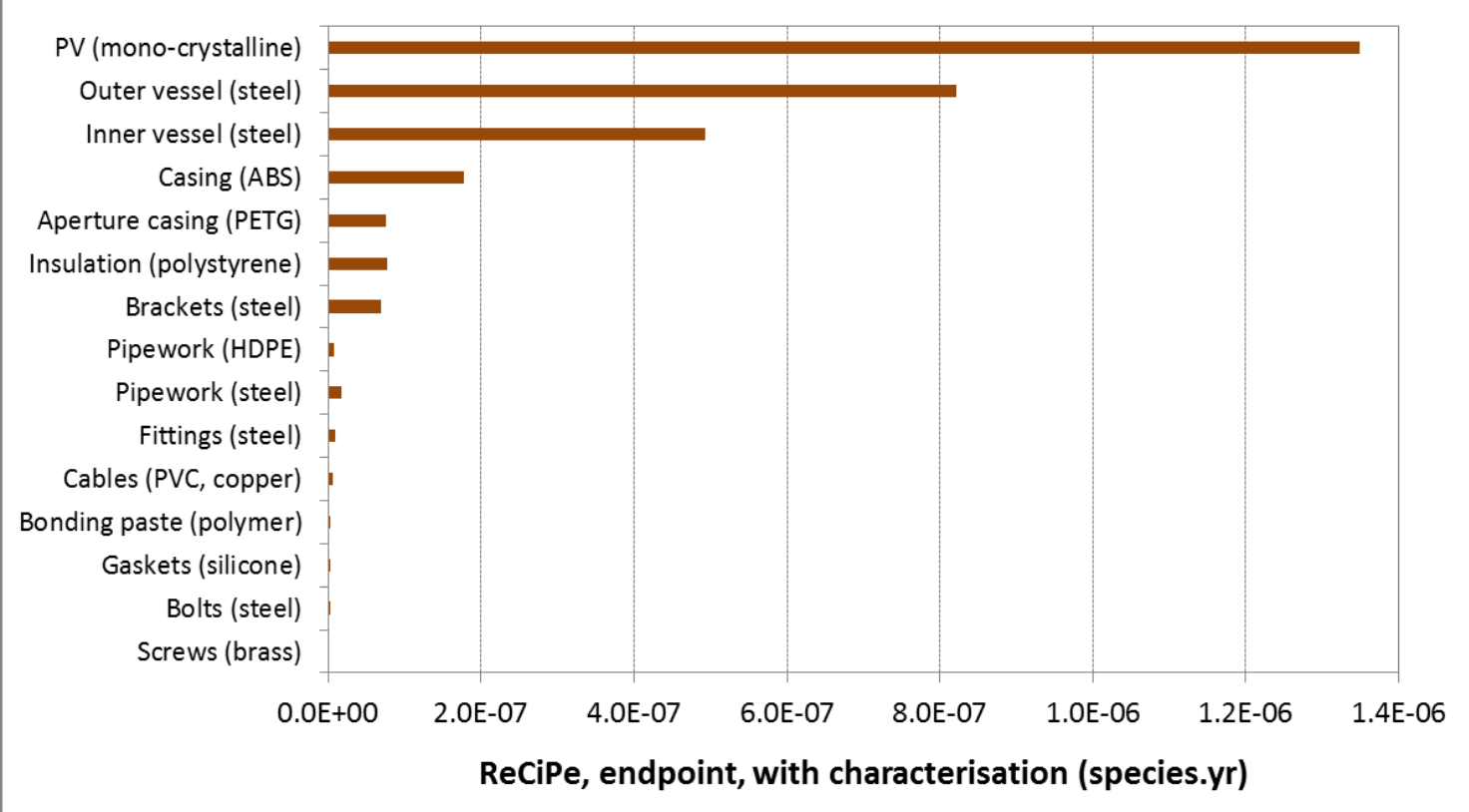

Figure 6. ReCiPe endpoint with characterisation: One PVT module. Results according to: a) DALY, b) (species.yr).

Results based on ReCiPe midpoint with characterisation

In Figure 7 the results in terms of Climate change (Figure 7a) and Ozone depletion (Figure 7b), are illustrated. It can be observed that: 
1) In both cases (Climate change; Ozone depletion) the PV cells and the two vessels show the highest impacts. Moreover, the difference between the impact of the PV cells and the impacts of the vessels is more pronounced for the category of Ozone depletion.

2) The category of Climate change for the PV cells and the two vessels presents values which range from 51.98 to $145.16 \mathrm{~kg} \mathrm{CO}_{2 . \text { eq. }}$

3) Regarding the category of Ozone depletion, the PV cells show an impact around 10 times higher in comparison to the impact of the inner vessel and about 6 times higher in comparison to the impact of the outer vessel.

In Figure 8 the findings according to Terrestrial acidification (Figure 8a) and Freshwater/marine eutrophication (Figure 8b) are presented, verifying that in all the cases the PV cells and the two vessels show the highest impacts. More analytically, the above mentioned three components show Terrestrial acidification values ranging from 0.32 to $0.85 \mathrm{~kg} \mathrm{SO}_{2}$ eq, Freshwater eutrophication values ranging from 0.02 to $0.06 \mathrm{~kg}$ $\mathrm{P}$ eq and Marine eutrophication values ranging from 0.01 to $0.06 \mathrm{~kg} \mathrm{~N}$ eq. With respect to Marine eutrophication, the impact of the PV cells is almost 3 times higher than the one of the outer vessel. Concerning Freshwater eutrophication, the impact of the PV cells is double than that of the outer vessel. 
a)

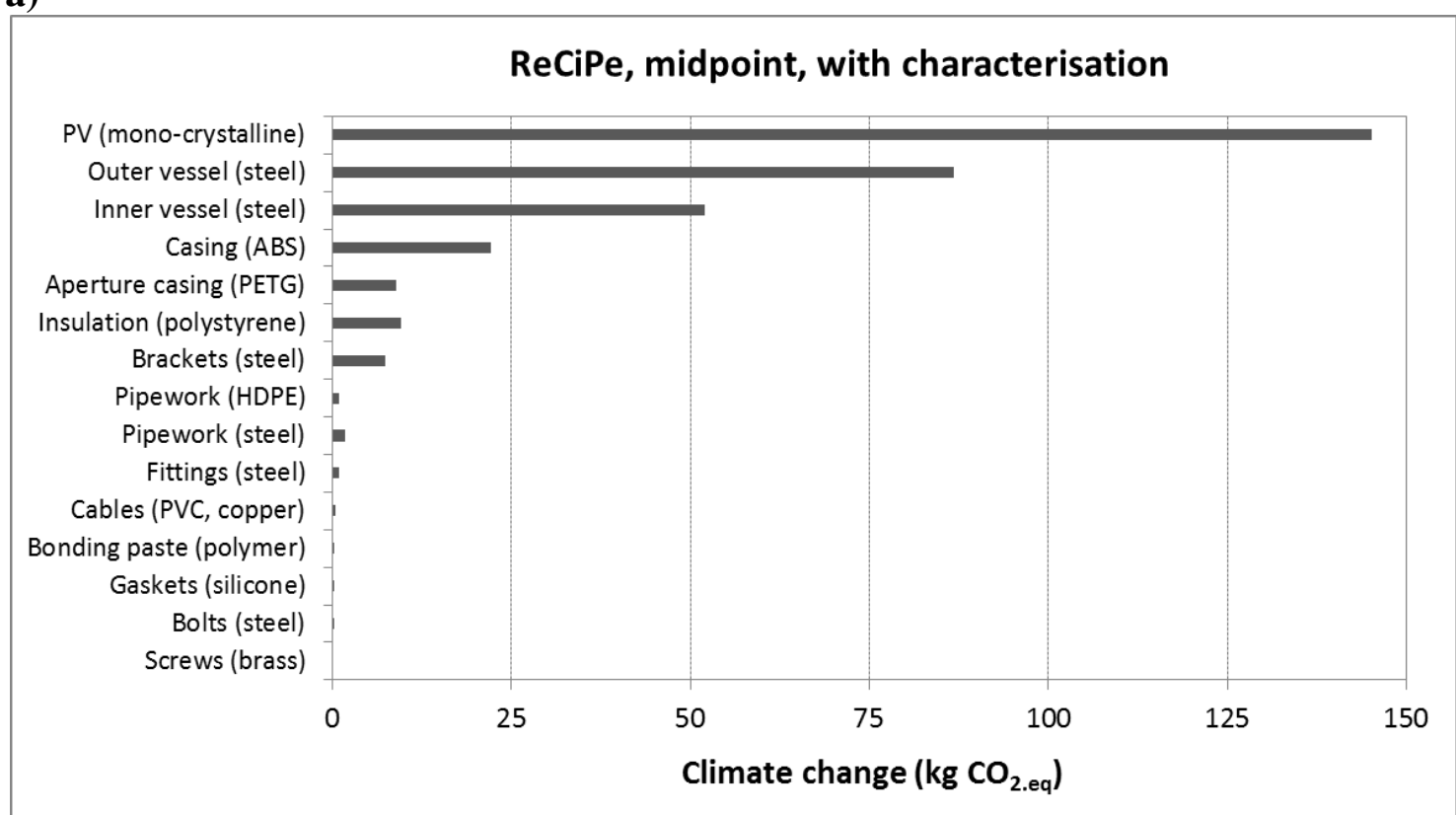

b)

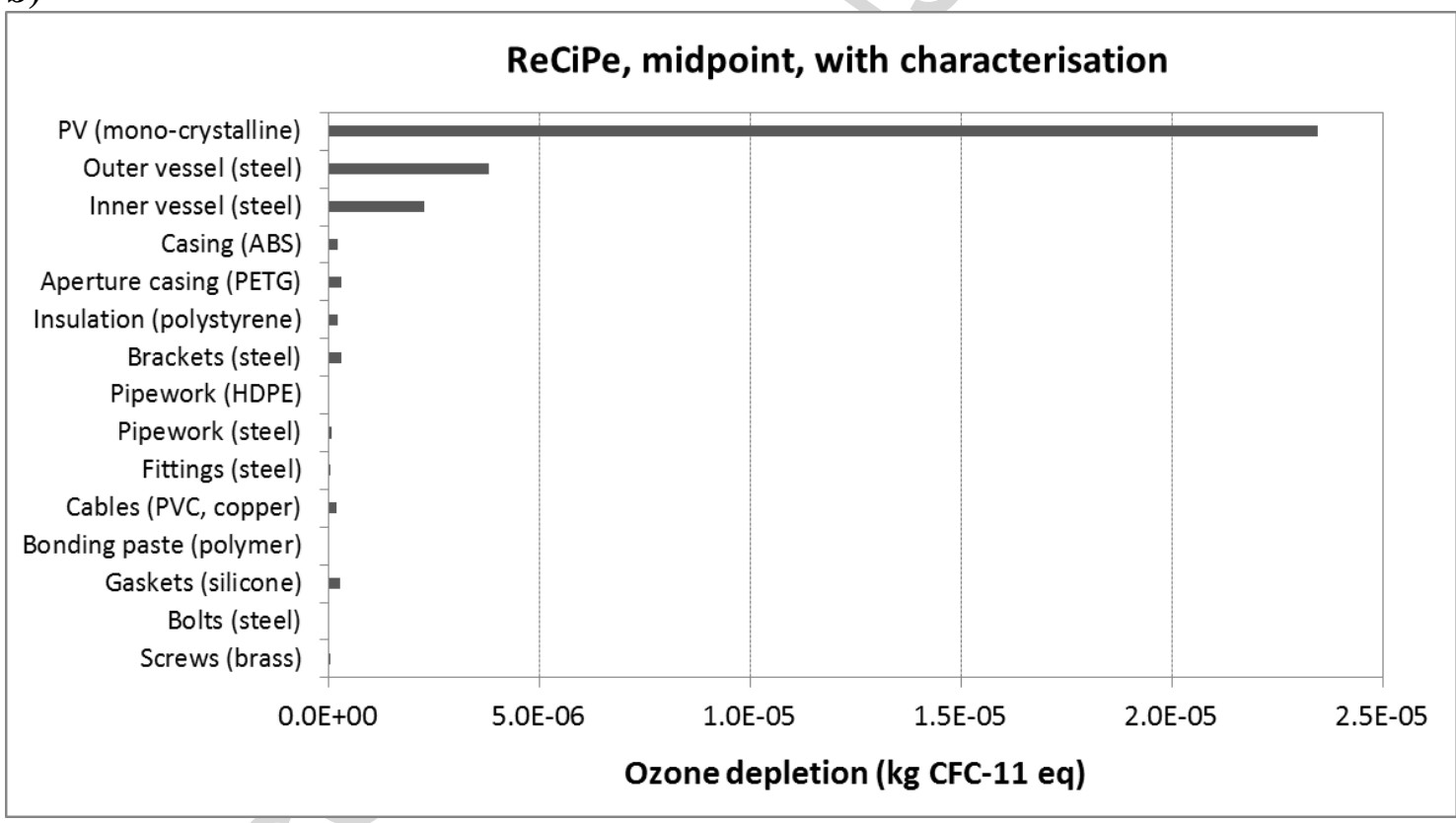

Figure 7. ReCiPe midpoint with characterisation: One PVT module. Results according to: a) Climate change, b) Ozone depletion. 
a)

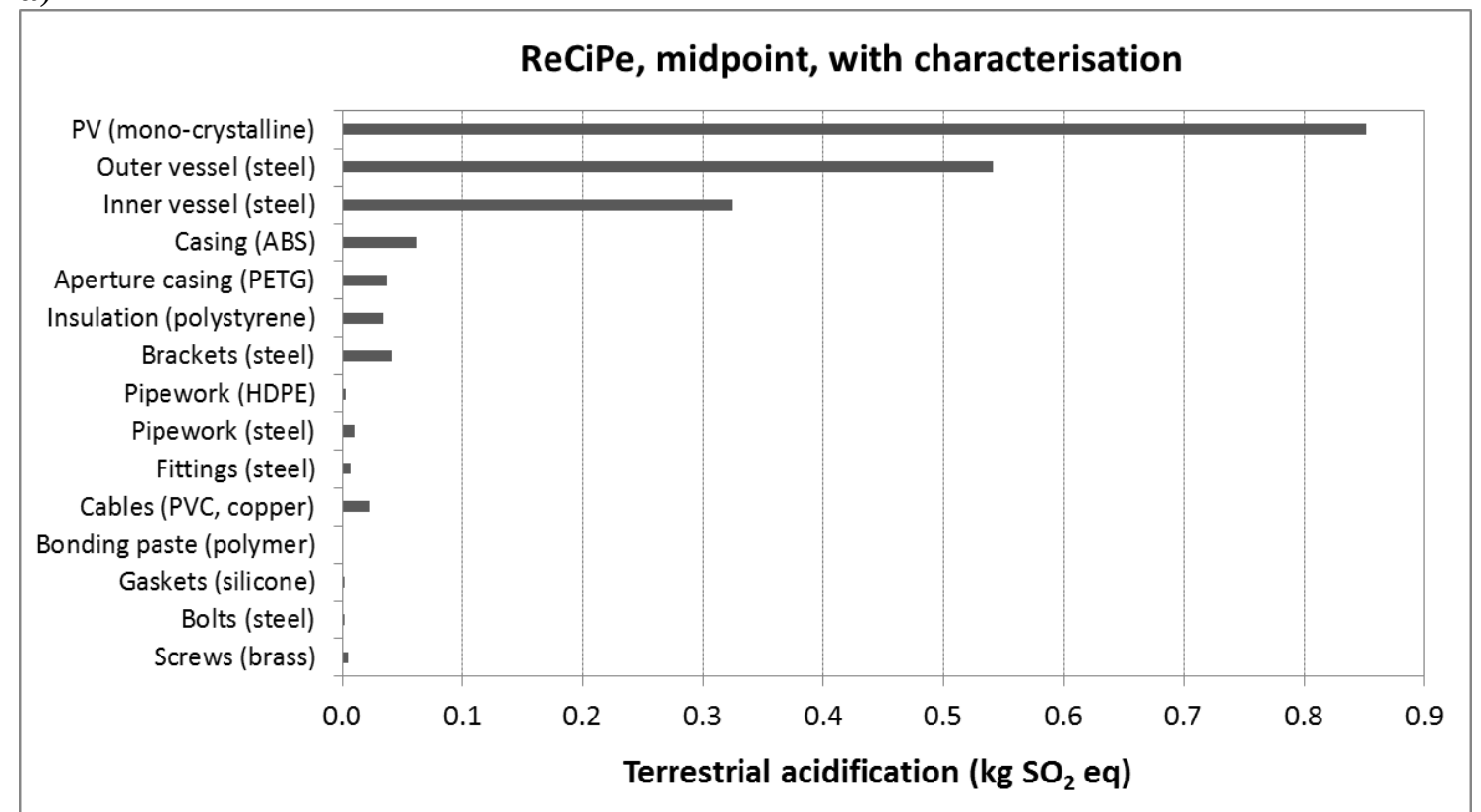

b)

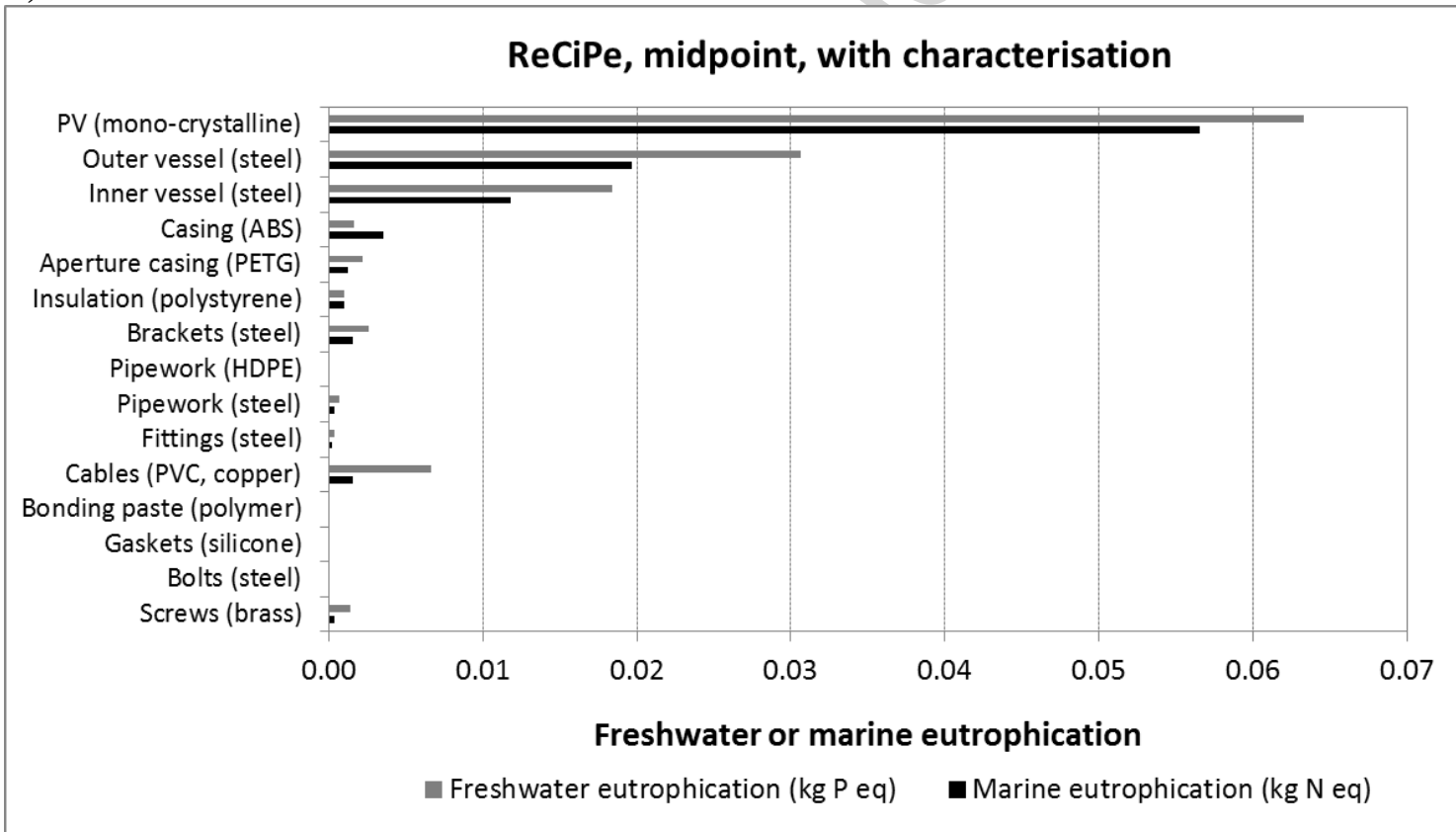

Figure 8. ReCiPe midpoint with characterisation: One PVT module. Results according to: a) Terrestrial acidification, b) Freshwater/marine eutrophication.

In Figure 9 additional findings based on ReCiPe midpoint with characterisation are presented. According to the category of Human toxicity (Figure 9a) as well as based on the categories of Marine/freshwater/terrestrial ecotoxicity (Figure 9b), the PV cells and the two vessels are the components with the three highest impacts. In addition, it can be noted that for Marine ecotoxicity and Freshwater ecotoxicity (Figure 9b) the two 
vessels show remarkably higher impact in comparison to the PV cells. Furthermore, by focusing on Figure $9 \mathrm{~b}$ it can be observed that, in general, Marine ecotoxicity and Freshwater ecotoxicity show considerably higher values in comparison to Terrestrial ecotoxicity. More analytically, for Freshwater ecotoxicity the outer vessel presents a value 5 times higher than the one of the PV cells. Regarding Marine ecotoxicity, the outer vessel shows around 4 times higher impact in comparison to the PV cells.

a)

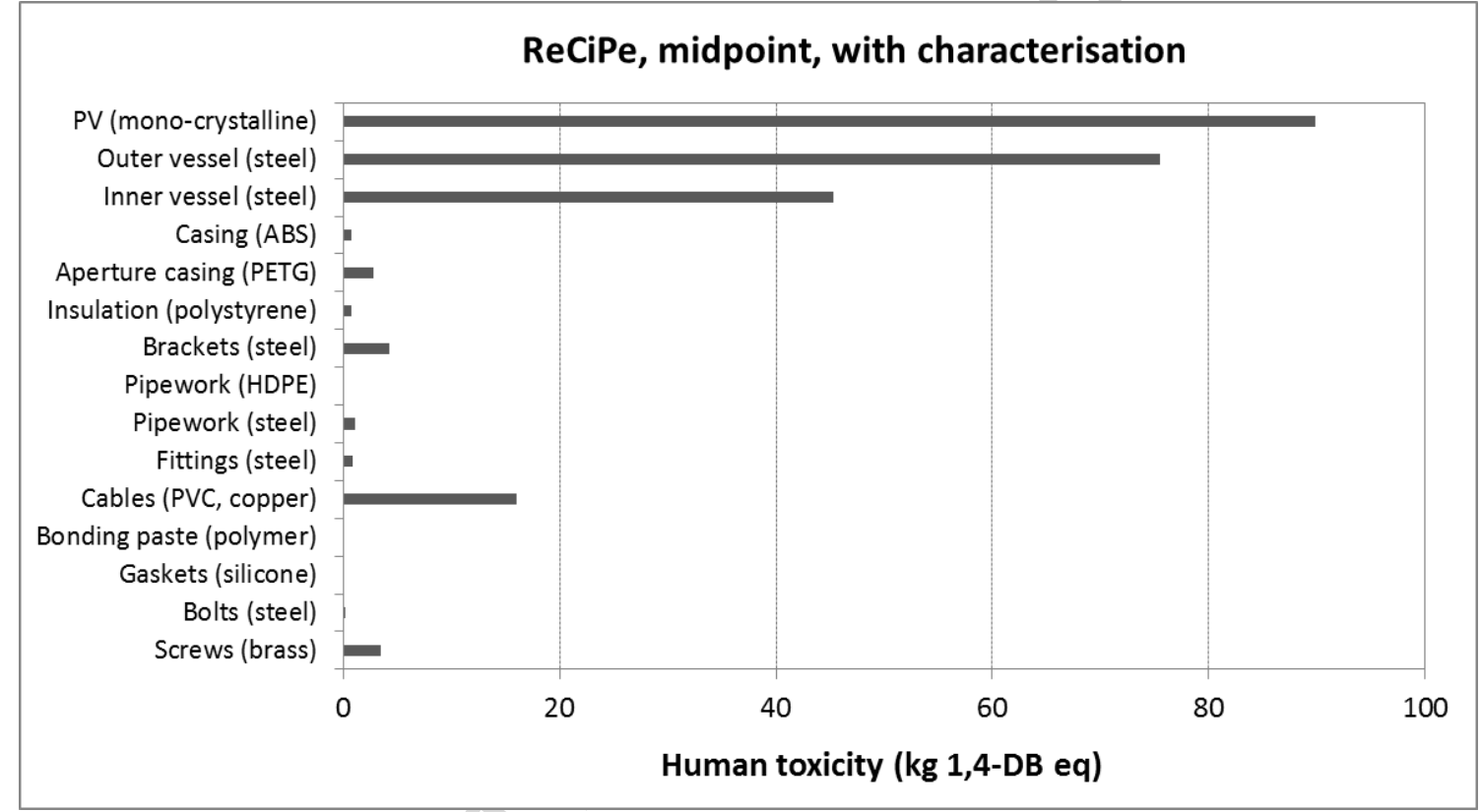

b)

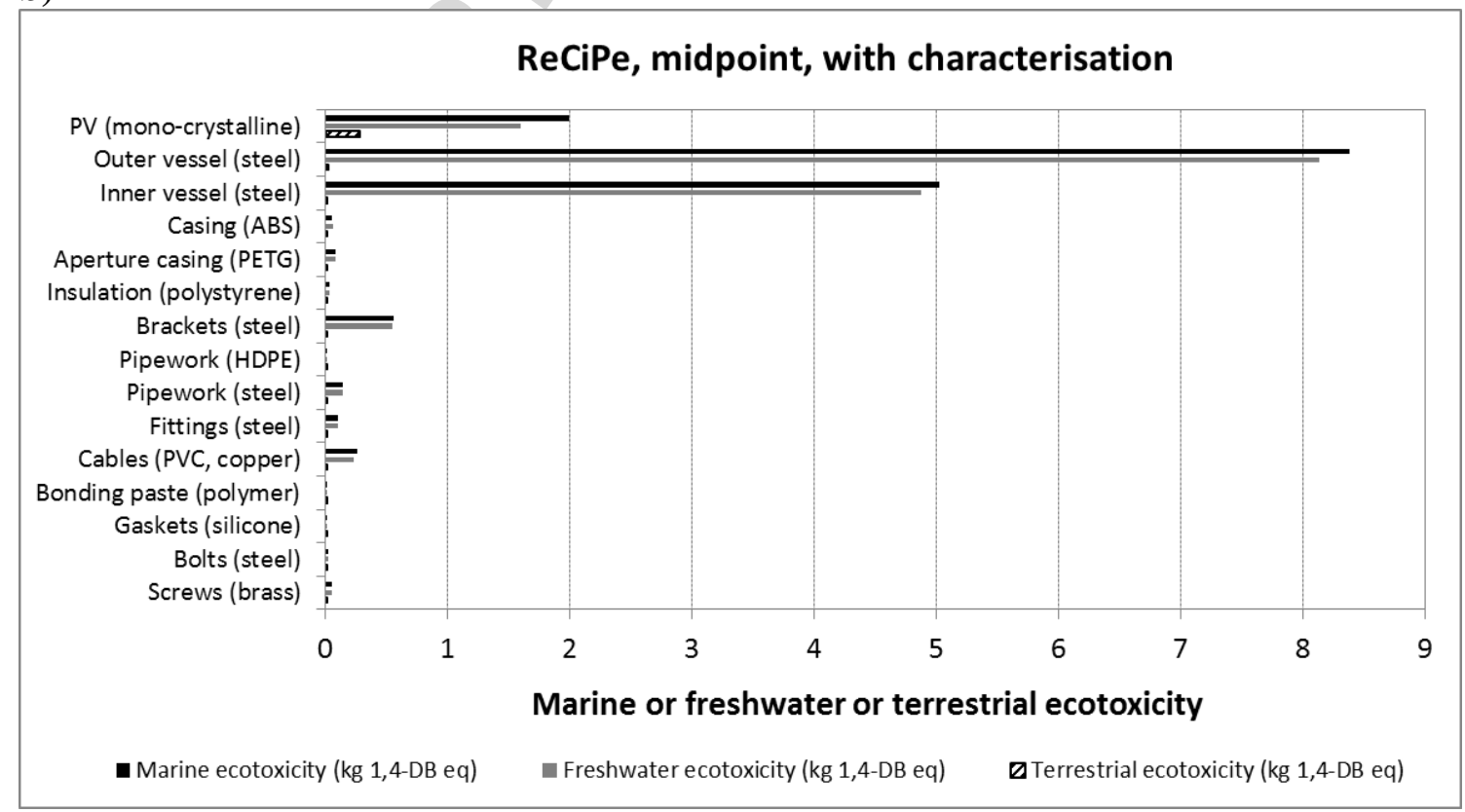

Figure 9. ReCiPe midpoint with characterisation: One PVT module. Results according to: a) Human toxicity, b) Marine/freshwater/terrestrial ecotoxicity. 
Based on ReCiPe midpoint with characterisation, the results for Photochemical oxidant formation (Figure 10) reveal that the PV cells and the two vessels present the highest impacts, ranging from 0.22 to $0.56 \mathrm{~kg}$ NMVOC. More analytical, in the case of Photochemical oxidant formation, the impact of the PV cells is around 3 times higher than the impact of the inner vessel.

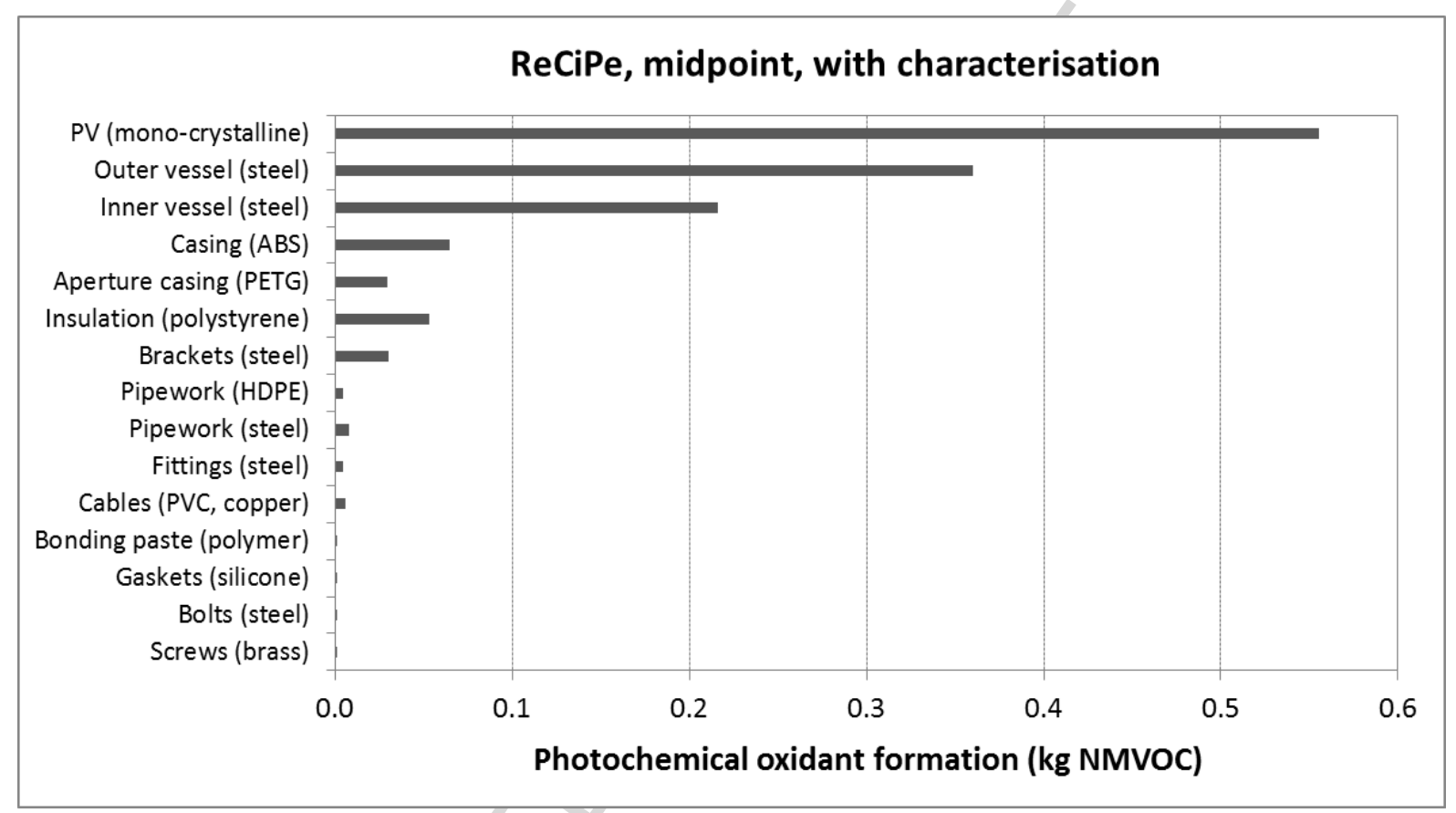

Figure 10. ReCiPe midpoint with characterisation: One PVT module. Results according to Photochemical oxidant formation.

By taking into account all the components of one PVT module and based on ReCiPe midpoint, in Table 4 the components with the two highest impacts in each midpoint category (PV cells; outer vessel) are indicated. It can be seen that the PV cells present the highest impact in 12 out of the 18 categories. The differences between the impacts of the PV cells and those of the outer vessel are especially pronounced in the case of Ozone depletion and Terrestrial ecotoxicity where the PV cells show about 6 and 13 times higher impact (in comparison to the outer vessel), respectively. For the impact categories of Climate change, Terrestrial acidification, Freshwater eutrophication, Marine eutrophication, Ionising radiation, Natural land transformation 
and Fossil depletion, the PV cells present around 2-3 times higher impact in comparison to the outer vessel. On the other hand, the outer vessel presents the highest impact in 6 out of the 18 midpoint categories. More analytically, these differences are more pronounced in the case of Freshwater ecotoxicity, Marine ecotoxicity and Metal depletion where the outer vessel presents about 5, 4 and 24 times higher impact (in comparison to the PV cells), respectively.

Table 4. ReCiPe midpoint with characterisation: The components of one PVT module with the highest impact in each midpoint category (indicated by X). Scenario «without recycling».

\begin{tabular}{|c|c|c|c|}
\hline $\begin{array}{l}\text { ReCiPe } \\
\text { midpoint } \\
\text { category }\end{array}$ & $\begin{array}{l}\text { Units of } \\
\text { each } \\
\text { category }\end{array}$ & Outer vessel & Comments \\
\hline Climate change & $\mathrm{kg} \mathrm{CO}_{2} \mathrm{eq}$ & $\mathrm{X}$ & $\begin{array}{l}\text { The impact of the PV cells is } 1.7 \\
\text { times higher in comparison to the } \\
\text { impact of the outer vessel }\end{array}$ \\
\hline Ozone depletion & $\begin{array}{l}\text { kg CFC-11 } \\
\text { eq }\end{array}$ & $X$ & $\begin{array}{l}\text { The impact of the PV cells is } 6.2 \\
\text { times higher in comparison to the } \\
\text { impact of the outer vessel }\end{array}$ \\
\hline $\begin{array}{l}\text { Terrestrial } \\
\text { acidification }\end{array}$ & $\mathrm{kg} \mathrm{SO}_{2} \mathrm{eq}$ & $\mathrm{X}$ & $\begin{array}{l}\text { The impact of the PV cells is } 1.6 \\
\text { times higher in comparison to the } \\
\text { impact of the outer vessel }\end{array}$ \\
\hline $\begin{array}{l}\text { Freshwater } \\
\text { eutrophication }\end{array}$ & $\mathrm{kg} \mathrm{P}$ eq & $X$ & $\begin{array}{l}\text { The impact of the PV cells is } 2.1 \\
\text { times higher in comparison to the } \\
\text { impact of the outer vessel }\end{array}$ \\
\hline $\begin{array}{l}\text { Marine } \\
\text { eutrophication }\end{array}$ & $\mathrm{kg} N$ eq & $X$ & $\begin{array}{l}\text { The impact of the PV cells is } 2.9 \\
\text { times higher in comparison to the } \\
\text { impact of the outer vessel }\end{array}$ \\
\hline Human toxicity & $\begin{array}{l}\mathrm{kg} 1,4-\mathrm{DB} \\
\mathrm{eq}\end{array}$ & $X$ & $\begin{array}{l}\text { The impact of the PV cells is } 1.2 \\
\text { times higher in comparison to the } \\
\text { impact of the outer vessel }\end{array}$ \\
\hline $\begin{array}{l}\text { Photochemical } \\
\text { oxidant formation }\end{array}$ & kg NMVOC & $X$ & $\begin{array}{l}\text { The impact of the PV cells is } 1.5 \\
\text { times higher in comparison to the } \\
\text { impact of the outer vessel }\end{array}$ \\
\hline $\begin{array}{l}\text { Particulate matter } \\
\text { formation }\end{array}$ & $\mathrm{kg}$ PM10 eq & $\mathrm{X}$ & $\begin{array}{l}\text { The impact of the outer vessel is } 1.5 \\
\text { times higher in comparison to the } \\
\text { impact of the PV cells }\end{array}$ \\
\hline $\begin{array}{l}\text { Terrestrial } \\
\text { ecotoxicity }\end{array}$ & $\begin{array}{l}\mathrm{kg} 1,4-\mathrm{DB} \\
\mathrm{eq}\end{array}$ & $X$ & $\begin{array}{l}\text { The impact of the PV cells is } 12.7 \\
\text { times higher in comparison to the } \\
\text { impact of the outer vessel }\end{array}$ \\
\hline
\end{tabular}




\begin{tabular}{|c|c|c|c|}
\hline $\begin{array}{l}\text { Freshwater } \\
\text { ecotoxicity }\end{array}$ & $\begin{array}{l}\mathrm{kg} 1,4-\mathrm{DB} \\
\text { eq }\end{array}$ & $X$ & $\begin{array}{l}\text { The impact of the outer vessel is } 5.1 \\
\text { times higher in comparison to the } \\
\text { impact of the PV cells }\end{array}$ \\
\hline $\begin{array}{l}\text { Marine } \\
\text { ecotoxicity }\end{array}$ & $\begin{array}{l}\text { kg 1,4-DB } \\
\text { eq }\end{array}$ & $X$ & $\begin{array}{l}\text { The impact of the outer vessel is } 4.2 \\
\text { times higher in comparison to the } \\
\text { impact of the PV cells }\end{array}$ \\
\hline Ionising radiation & $\begin{array}{l}\mathrm{kBq} \mathrm{U} 235 \\
\mathrm{eq}\end{array}$ & $X$ & $\begin{array}{l}\text { The impact of the PV cells is } 2.4 \\
\text { times higher in comparison to the } \\
\text { impact of the outer vessel }\end{array}$ \\
\hline $\begin{array}{l}\text { Agricultural land } \\
\text { occupation }\end{array}$ & $\mathrm{m}^{2} \mathrm{a}$ & $X$ & $\begin{array}{l}\text { The impact of the PV cells is } 1.4 \\
\text { times higher in comparison to the } \\
\text { impact of the outer vessel }\end{array}$ \\
\hline $\begin{array}{l}\text { Urban land } \\
\text { occupation }\end{array}$ & $\mathrm{m}^{2} \mathrm{a}$ & $X$ & $\begin{array}{l}\text { The impact of the outer vessel is } 1.6 \\
\text { times higher in comparison to the } \\
\text { impact of the PV cells }\end{array}$ \\
\hline $\begin{array}{l}\text { Natural land } \\
\text { transformation }\end{array}$ & $\mathrm{m}^{2}$ & $X$ & $\begin{array}{l}\text { impact of the PV cells is } 1.9 \\
\text { higher in comparison to the } \\
\text { ct of the outer vessel }\end{array}$ \\
\hline Water depletion & $\mathrm{m}^{3}$ & & $\begin{array}{l}\text { The impact of the outer vessel is } 1.1 \\
\text { times higher in comparison to the } \\
\text { impact of the PV cells }\end{array}$ \\
\hline Metal depletion & $\mathrm{kg} \mathrm{Fe}$ eq & $\Lambda$ & $\begin{array}{l}\text { The impact of the outer vessel is } \\
23.5 \text { times higher in comparison to } \\
\text { the impact of the PV cells }\end{array}$ \\
\hline Fossil depletion & $\mathrm{kg}$ oil eq & & $\begin{array}{l}\text { The impact of the PV cells is } 1.7 \\
\text { times higher in comparison to the } \\
\text { impact of the outer vessel }\end{array}$ \\
\hline
\end{tabular}

\section{Results based on EF}

In Figure 11, the findings based on EF single-score are illustrated and it can be observed that the category of Carbon dioxide shows considerably higher impact in comparison to the other two categories (Nuclear; Land occupation) for all the components of the PVT module. More specifically, the contribution of Carbon dioxide to the total impact (Carbon dioxide; Nuclear; Land occupation) ranges from $72 \%$ to 92\%, depending on the component of the PVT module. In terms of the components/materials with the highest EF impact (Figure 11), these are the PV cells and the two vessels, showing values which range from 128 to 349 Pts (in the case of Carbon 
dioxide). In addition, for the category of Carbon dioxide, the impact of the PV cells is 135 Pts higher than the one of the outer vessel.

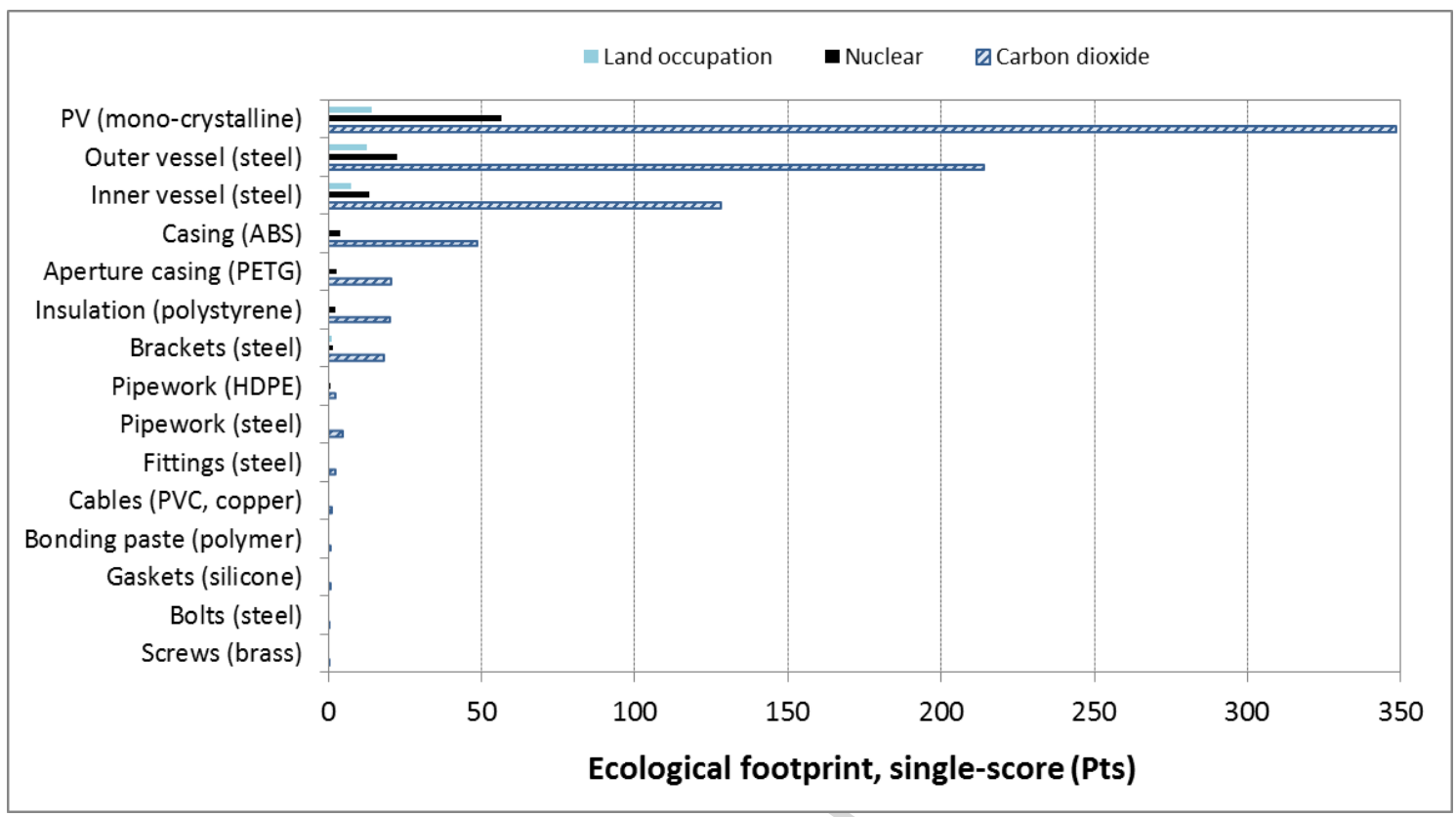

Figure 11. Ecological footprint single-score: One PVT module. Results according to Land occupation, Nuclear and Carbon dioxide.

\section{Results based on USEtox}

In Figure 12 the results based on USEtox are illustrated and it can be observed that the PV cells and the two vessels show the highest values in terms of Human toxicity (Figure 12a) as well as in terms of Ecotoxicity (Figure 12b). More analytically, for the PV cells, Human toxicity/cancer and Human toxicity/non-cancer have close values. On the other hand, for the vessels, Human toxicity/cancer presents remarkably higher values than Human toxicity/non-cancer. In addition, the findings based on Ecotoxicity (Figure 12b) reveal that the PV cells have around 3-4 times higher impact than the vessels. 
a)

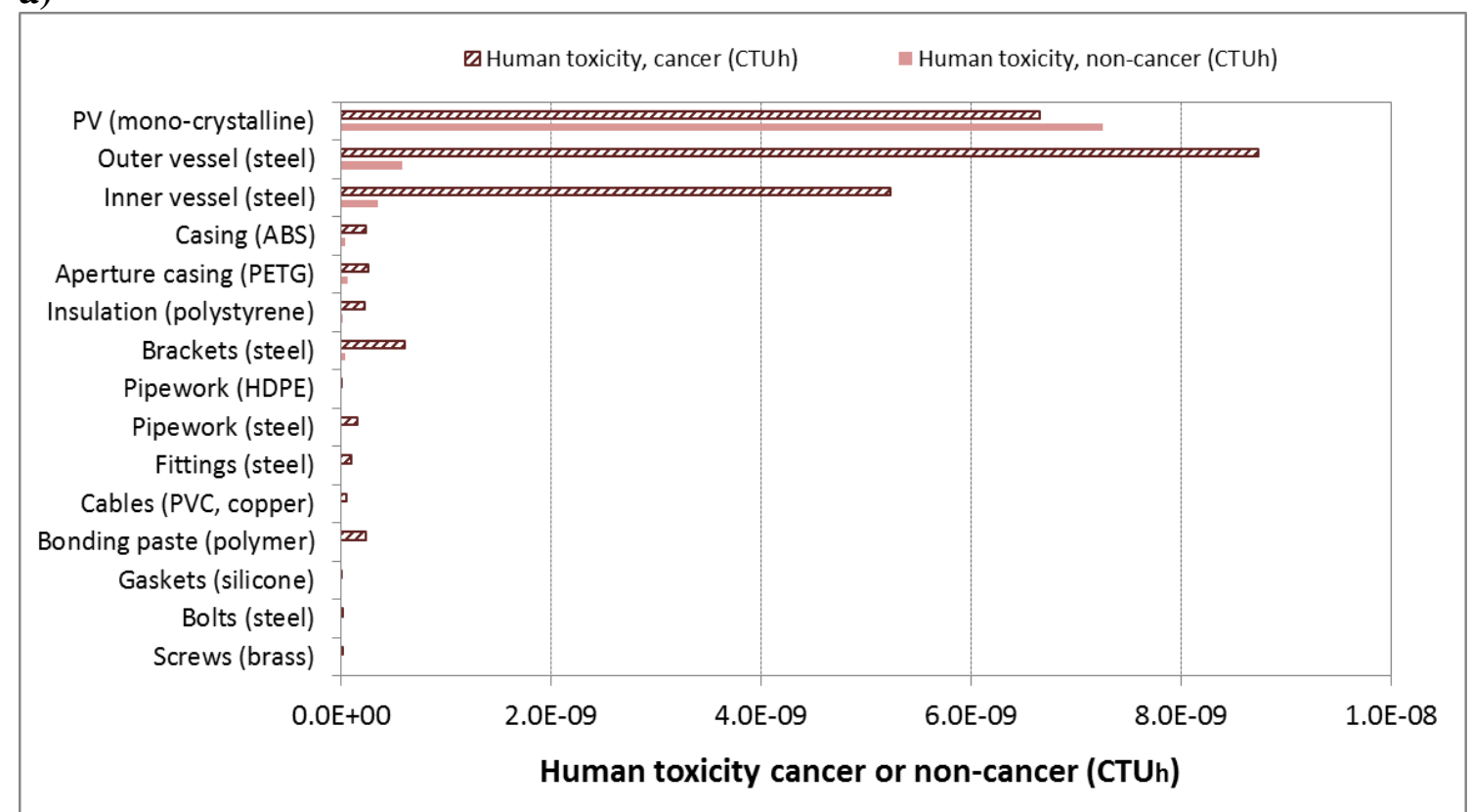

b)

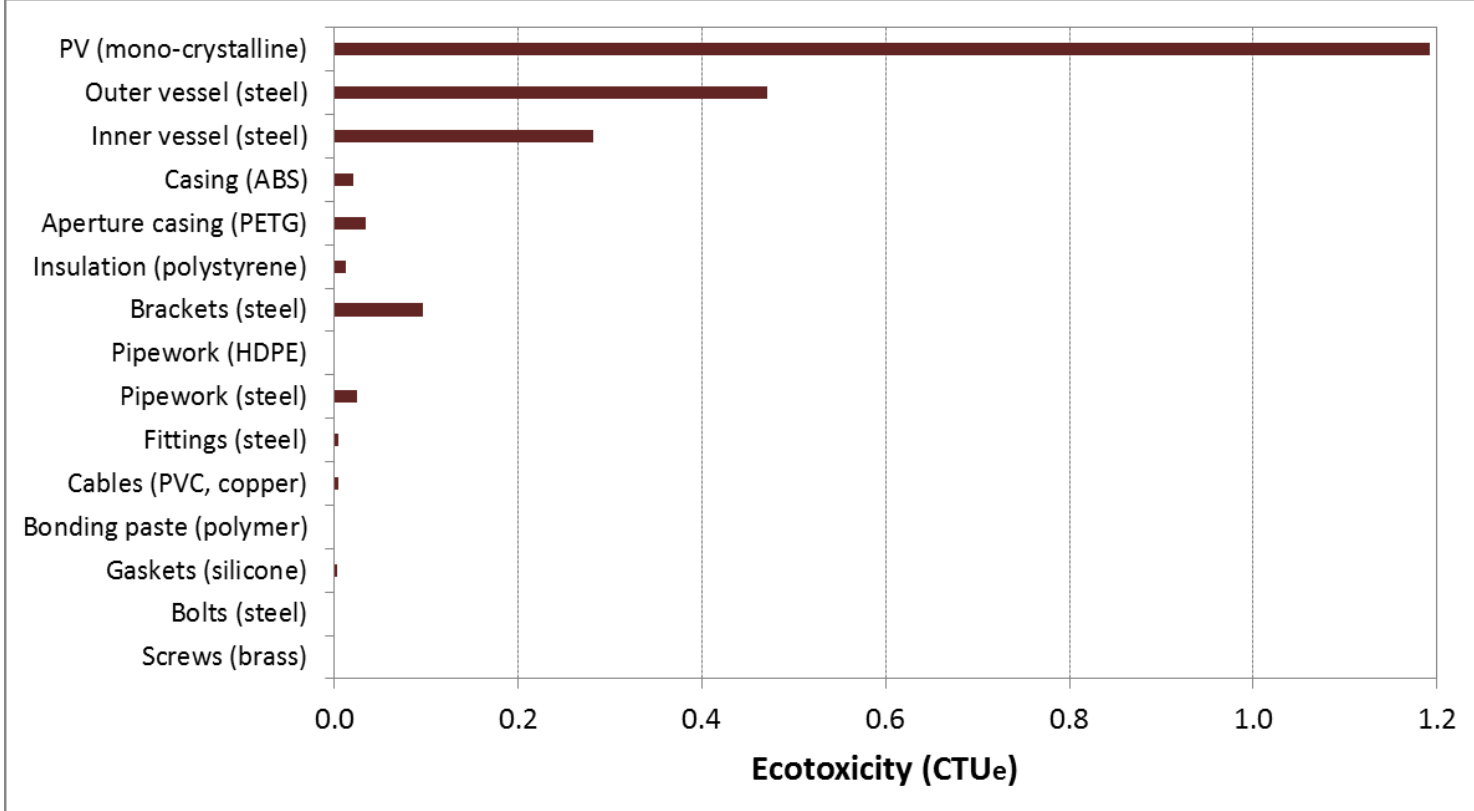

Figure 12. USEtox: One PVT module. Results according to: a) Human toxicity (cancer and non-cancer) and b) Ecotoxicity.

\section{Discussion about the contribution of each component to the total impact}

In Table 5, the contribution of the PV cells and the outer vessel to the total impact of one PVT module is given. In each case, the component with the highest contribution is indicated by X. From Table 5, it can be seen that: 
1) In 9 out of the 11 studied cases, the PV cells present the highest percentages, showing contributions which range from $37 \%$ to $86 \%$. The highest percentage of $86 \%$ has been found in the case of USEtox human toxicity/non-cancer.

2) The outer vessel has the second highest contribution, showing in two cases (ReCiPe endpoint single-score; USEtox human toxicity/cancer) percentages of $39 \%$.

Table 5. The contributions of the PV cells and the outer vessel to the total impact of one PVT module. In each case, the component with the highest contribution is indicated by $\mathrm{X}$.

\begin{tabular}{|c|c|c|}
\hline Methods/environmental indicators & PV cells & Outer vessel \\
\hline CED & $\mathrm{X}(40 \%)$ & \\
\hline GWP 20a & X (42\%) & \\
\hline GWP 100a & X (43\%) & \\
\hline GWP 500a & X (43\%) & \\
\hline ReCiPe endpoint single-score (Pts) & & $X(39 \%)$ \\
\hline ReCiPe endpoint with characterisation (DALY & $X(37 \%)$ & \\
\hline ReCiPe endpoint with characterisation (species.yr & $X(43 \%)$ & \\
\hline EF single-score (Pts): Carbon dioxide & $X(43 \%)$ & \\
\hline USEtox, human toxicity/cancer $\left(\mathrm{CTU}_{\mathrm{h}}\right)$ & & $X(39 \%)$ \\
\hline USEtox, human toxicity/non-cancer $\left(\mathrm{CTU}_{\mathrm{h}}\right)$ & $X(86 \%)$ & \\
\hline USEtox, ecotoxicity $\left(\mathrm{CTU}_{\mathrm{e}}\right)$ & $\mathrm{X}(55 \%)$ & \\
\hline
\end{tabular}

In light of the findings presented above, it should be noted that the impact of the PV cells is mainly associated with the processes for the conversion of silicon (single crystal) to single-silicon wafer and PV cell. PV-cell production is based on the Czochralski process (Sources: SimaPro; ecoinvent). Details about PV-cell production in the case of silicon-based PV cells (mining of silica, production of crystalline silicon wafer, chemical processes, treatments in high temperatures, etc.) have been presented in the review article by Lamnatou and Chemisana (2017).

Regarding steel, the greatest part of its impact is due to the heat inputs necessary for the production of ferronickel (Sources: SimaPro; ecoinvent). Certainly, by using less steel (or by adopting alternative materials instead of steel) for the manufacturing of the proposed PVT module, a reduction of the environmental impact can be achieved.

Given the fact that the findings of the present study (Table 5) reveal that the PV cells are responsible for the highest impact in most of the studied cases, the 
environmental profile of crystalline-silicon PV modules is following discussed: In the review article of $\mathrm{Hsu}$ et al. (2012) factors which influence the environmental performance of crystalline-silicon PV cells were analysed. It was noted that the lifecycle of a crystalline-silicon PV system includes different phases. For instance, the upstream phase begins with the acquisition of raw materials (silica sand, etc.). Energy is required to process the raw materials into e.g. crystalline silicon and steel. Energy is then necessary in order to manufacture the components of a PV module/system. A PV system also includes the balance-of-system (structural support, wiring, inverters, etc.) as well as inputs related to transportation and installation. Hsu et al. (2012) highlighted that the main environmental impact is associated with the stages before the operational phase. Certainly, the phase of operation includes some inputs such as replacement of inverters and substitution of any components that break but PV systems have minimal operation and maintenance needs and, therefore, the environmental impact during this stage is low. Moreover, recycling is a critical issue (Hsu et al., 2012).

\subsubsection{Phase of material manufacturing and disposal: One PVT module (recycling of certain materials)}

The disposal of the materials of one PVT module has been examined based on two scenarios: 1) Landfill for all the materials, 2) Recycling of steel, plastics and brass (landfill for the other materials). The results show that by adopting recycling there is a considerable environmental benefit. The data sources, for both recycling and landfill scenarios, are SimaPro 8 and ecoinvent 3 database. In Table 6, the findings are presented and it can be seen that steel recycling offers a remarkable impact reduction ranging from $47 \%$ to $85 \%$, depending on the case. 
Table 6. Percentages of impact reduction due to recycling. Disposal: One PVT module.

\begin{tabular}{llllll}
\hline Materials & $\begin{array}{l}\text { Impact } \\
\text { reduction in } \\
\text { terms of CED }\end{array}$ & $\begin{array}{l}\text { Impact } \\
\text { reduction in } \\
\text { terms of } \\
\text { GWP 100a }\end{array}$ & $\begin{array}{l}\text { Impact reduction in } \\
\text { terms of Human } \\
\text { health (ReCiPe } \\
\text { endpoint) }\end{array}$ & $\begin{array}{l}\text { Impact reduction } \\
\text { in terms of } \\
\text { Ecosystems } \\
\text { (ReCiPe } \\
\text { endpoint) }\end{array}$ & $\begin{array}{l}\text { Impact reduction } \\
\text { in terms of } \\
\text { Resources } \\
\text { (ReCiPe } \\
\text { endpoint) }\end{array}$ \\
\hline Steel & $47 \%$ & $79 \%$ & $85 \%$ & $80 \%$ & $67 \%$ \\
\hline Plastics & $53 \%$ & $21 \%$ & $15 \%$ & $20 \%$ & $33 \%$
\end{tabular}

In relation to the issues mentioned above, Xue et al. (2018) noted that there is an increasing interest in recycling of metals since by means of recycling multiple environmental benefits such as resource conservation and reduction in greenhouse-gas emissions can be obtained. Regarding the use of steel and aluminium in constructions, Meneghelli (2018) mentioned that these two materials are commonly used in buildings and $\mathrm{CO}_{2}$ emissions that are associated with the manufacturing phase of these two materials should be considered as part of the embodied carbon of the whole building/construction. Concerning steel production, Olmez et al. (2016) investigated the environmental impacts of iron and steel industry, based on LCA. It was mentioned that among the processes, steel making showed the highest total environmental impact, followed by sintering. More analytically, the highest impacts were found in the categories of Human health and Climate change. Moreover, the processes of coke production presented the highest impact in terms of the depletion of non-renewable energy sources (Olmez et al., 2016).

\subsubsection{Comparisons of the results of the present LCA study with the literature}

In Table 7 the findings of the present study (according to CED and GWP) are compared with the literature (BIPVT and BA PVT configurations) and it can be seen that, in general, there is a good agreement. In addition, from Table 7 it can be seen that most of the cases present around $5 \mathrm{GJ}$ and $0.4 \mathrm{t} \mathrm{CO}_{2 \text {.eq }}$ per $\mathrm{m}^{2}$ of PVT module (BI or BA). 
Table 7. Comparisons of the present study with the literature.

\begin{tabular}{|c|c|c|c|c|c|c|}
\hline $\begin{array}{l}\text { STUDY / TYPE } \\
\text { OF BUILDING } \\
\text { INTEGRATION }\end{array}$ & $\begin{array}{l}\text { TYPE OF PV } \\
\text { CELLS }\end{array}$ & $\begin{array}{l}\text { WORKING } \\
\text { FLUID }\end{array}$ & $\begin{array}{l}\text { TYPE OF } \\
\text { SYSTEM, } \\
\text { APPLICATION, } \\
\text { ETC. }\end{array}$ & $\begin{array}{l}\text { ENVINMENTAL } \\
\text { ISSUES STUDIED }\end{array}$ & $\begin{array}{l}\text { REFERENCE } \\
\text { AREA OF THE } \\
\text { SYSTEM }\end{array}$ & $\begin{array}{l}\text { RESULTS FOR THE } \\
\text { PHASE OF MATERIAL } \\
\text { MANUFACTURING }\end{array}$ \\
\hline $\begin{array}{l}\text { Present study } \\
\text { / BI }\end{array}$ & $\begin{array}{l}\text { Mono- } \\
\text { crystalline } \\
\text { silicon }\end{array}$ & Water & $\begin{array}{l}\text { BIPVT for } \\
\text { domestic } \\
\text { water heating }\end{array}$ & $\begin{array}{l}\text { CED, GWP, } \\
\text { ReCiPe, EF, USEtox }\end{array}$ & $\begin{array}{l}1 \mathrm{~m}^{2} \text { thermal } \\
\text { absorber }\end{array}$ & $\begin{array}{l}\mathbf{4 . 9 2} \mathbf{G J}_{\text {prim }}(\mathrm{CED}) \\
\mathbf{0 . 3 4} \text { t } \mathbf{C O}_{2 . \text { eq }}(\mathrm{GWP} \\
100 \mathrm{a})\end{array}$ \\
\hline $\begin{array}{l}\text { Tripanagnost } \\
\text { opoulos et al. } \\
(2005) / \text { BA }\end{array}$ & $\begin{array}{l}\text { Multi- } \\
\text { crystalline } \\
\text { silicon }\end{array}$ & Water & $\begin{array}{l}\mathrm{PV} \text { and PVT } \\
\text { systems for } \\
\text { roofs }\end{array}$ & $\begin{array}{l}\text { Embodied energy, } \\
\mathrm{CO}_{2 . \text { eq }} \text { emissions }\end{array}$ & $\begin{array}{l}30 \mathrm{~m}^{2} \\
\text { aperture area }\end{array}$ & $\begin{array}{l}\text { Expected values for } 1 \\
\mathrm{~m}^{2} \text { aperture area: } \\
\text { 4.94 GJ LHV } \\
\mathbf{0 . 4 3} \text { t } \mathbf{C O}_{2 . \text { eq }} \text { (GWP } \\
\text { 100a); Studied system: } \\
\text { with glazing covering } \\
\text { and aluminium } \\
\text { reflectors, horizontal } \\
\text { roof }\end{array}$ \\
\hline $\begin{array}{l}\text { Battisti and } \\
\text { Corrado } \\
(2005) / \\
\text { Several } \\
\text { configuration } \\
\text { s }\end{array}$ & $\begin{array}{l}\text { Multi- } \\
\text { crystalline } \\
\text { silicon }\end{array}$ & Air & $\begin{array}{l}\text { PV and PVT } \\
\text { systems for } \\
\text { roofs }\end{array}$ & $\begin{array}{l}\mathrm{CED}, \mathrm{CO}_{2 . e q} \\
\text { emissions }\end{array}$ & dule & $\begin{array}{l}\text { 5.15 GJ LHV } \\
0.46 \text { t } \mathrm{CO}_{2 . \mathrm{eq}}\end{array}$ \\
\hline $\begin{array}{l}\text { Tripanagnost } \\
\text { opoulos et al. } \\
(2006) \text { / BA }\end{array}$ & $\begin{array}{l}\text { Multi- } \\
\text { crystalline } \\
\text { silicon }\end{array}$ & Air & $\begin{array}{l}\text { PV and PVT } \\
\text { systems for } \\
\text { roofs }\end{array}$ & $\begin{array}{l}\text { Embodied energy, } \\
\mathrm{CO}_{2 . \mathrm{eq}} \text { emissions }\end{array}$ & $\begin{array}{l}30 \mathrm{~m}^{2} \\
\text { aperture area }\end{array}$ & $\begin{array}{l}\text { Expected values for } 1 \\
\mathrm{~m}^{2} \text { aperture area: } \\
\text { 4.59 GJ LHV } \\
\text { 0.41 t CO } \text { C.eq }_{\text {.eq }} \text { (GWP } \\
\text { 100a); Studied system: } \\
\text { with glazing covering } \\
\text { and aluminium } \\
\text { reflectors, horizontal } \\
\text { roof }\end{array}$ \\
\hline $\begin{array}{l}\text { Sun }(2014) / \\
\text { BI }\end{array}$ & $\begin{array}{l}\text { Mono- } \\
\text { crystalline } \\
\text { silicon }\end{array}$ & Water & $\begin{array}{l}\text { Residential } \\
\text { home } \\
\text { integration }\end{array}$ & $\begin{array}{l}\text { CED, GWP 100a, } \\
\text { etc. }\end{array}$ & $\begin{array}{l}1 \mathrm{~m}^{2} \text { silicon- } \\
\text { based solar } \\
\text { cell }\end{array}$ & $\begin{array}{l}\text { 4.60 GJ } \\
0.43 \text { t CO } \mathbf{C O}_{2 . \mathrm{eq}} \\
(\mathrm{GWP} 100 \mathrm{a})\end{array}$ \\
\hline
\end{tabular}

\subsection{Future prospects of the present LCA study}

The present investigation can be extended in order to examine the full life-cycle of the proposed PVT module, by taking into account PVT output in terms of thermal energy and electricity in the frame of a real façade-integrated application. In this case, environmental indicators such as EPBT, greenhouse-gas PBT and ReCiPe PBT could be calculated. In addition, it would be useful to evaluate the life-cycle impact per $\mathrm{kWh}$ of energy produced and compare the results with the impact of other PVT systems from the literature. In the frame of a full life-cycle study, additional phases of the life-cycle of a real PVT system such as installation, replacement of certain components during system lifespan, transportation and disposal could be taken into account. 


\section{CONCLUSIONS}

An environmental LCA study (according to CED, GWP, ReCiPe, EF and USEtox) about a BIPVT prototype is presented.

Based on all the adopted methods and environmental indicators and by taking into account primary materials the results show that the PV cells, the inner vessel (steel) and the outer vessel (steel) are the components with the three highest impacts. In terms of the contribution of each component to the total impact of one PVT module (scenario based on primary materials), the PV cells present the highest contributions in 9 out of the 11 studied cases, showing percentages ranging from $37 \%$ to $86 \%$ (the percentage of $86 \%$ has been found in the case of USEtox human toxicity/non-cancer). In addition, the outer vessel has the second highest contribution, showing in two cases (ReCiPe endpoint single-score; USEtox human toxicity/cancer) percentages of $39 \%$.

Scenarios with recycling of steel, plastics and brass (landfill for the other materials), based on CED, GWP 100a and ReCiPe endpoint, have been evaluated. The findings show that steel recycling offers a considerable impact reduction ranging from $47 \%$ to $85 \%$, depending on the case.

With respect to the impact of the proposed PVT module per $\mathrm{m}^{2}$ of thermal absorber (scenario based on primary materials), the following values have been found: $4.92 \mathrm{GJ}_{\text {prim }} / \mathrm{m}^{2}$ and $0.34 \mathrm{t} \mathrm{CO}_{2 . \mathrm{eq}} / \mathrm{m}^{2}$ (according to GWP 100a). A comparison with the literature shows a good agreement.

A separate section with factors that influence the environmental profile of a BIPVT system has been included, highlighting issues such as the materials of the storage system and the use of recycled materials instead of primary ones.

\section{ACKNOWLEDGEMENTS}

The authors would like to thank "Ministerio de Economía y Competitividad" of Spain for the funding (grant reference ENE2016-81040-R). 


\section{REFERENCES}

Abdolzadeh, M., Sadeqkhani, M., Ahmadi, A., 2017. Computational modeling of a BIPV/T ethylene tetrafluoroethylen (ETFE) cushion structure roof. Energy 133, 9981012.

Agathokleous, R.A., Kalogirou, S.A., Karellas, S., 2018. Exergy analysis of a naturally ventilated Building Integrated Photovoltaic/Thermal (BIPV/T) system. Renew. Energy $128,541-552$.

Agrawal, S., Tiwari, G.N., 2015. Performance analysis in terms of carbon credit earned on annualized uniform cost of glazed hybrid photovoltaic thermal air collector. Solar Energy 115, 329-340.

Anderson, T.N., Duke, M., Morrison, G.L., Carson, J.K., 2009. Performance of a building integrated photovoltaic/thermal (BIPVT) solar collector. Solar Energy 83, 445455 .

Asaee, S.R., Nikoofard, S., Ugursal, V.I., Beausoleil-Morrison, I., 2017. Technoeconomic assessment of photovoltaic (PV) and building integrated photovoltaic/thermal (BIPV/T) system retrofits in the Canadian housing stock. Energy Build. 152, 667-679.

Assoa, Y.B., Sauzedde, F., Boillot, B., Boddaert, S., 2017. Development of a building integrated solar photovoltaic/thermal hybrid drying system. Energy 128, 755-767.

Battisti, R., Corrado, A., 2005. Evaluation of technical improvements of photovoltaic systems through life cycle assessment methodology. Energy 30, 952-967.

Bazán, J., Rieradevall, J., Gabarrell, X., Vázquez-Rowe, I., 2018. Low-carbon electricity production through the implementation of photovoltaic panels in rooftops in urban environments: A case study for three cities in Peru. Sci. Tot. Environ. 622-623, $1448-1462$.

Bigaila, E., Athienitis, A.K., 2017. Modeling and simulation of a photovoltaic/thermal air collector assisting a façade integrated small scale heat pump with radiant PCM panel. Energy Build. 149, 298-309.

Buker, M.S., Mempouo, B., Riffat, S.B., 2014. Performance evaluation and technoeconomic analysis of a novel building integrated PV/T roof collector: An experimental validation. Energy Build. 76, 164-175.

Buonomano, A., Calise, F., Palombo, A., Vicidomini, M., 2017. Adsorption chiller operation by recovering low-temperature heat from building integrated photovoltaic thermal collectors: Modelling and simulation. Energy Convers. Manage. 149, 10191036.

Cappelletti, A., Nelli, L.C., Reatti, A., 2018. Integration and architectural issues of a photovoltaic/thermal linear solar concentrator. Solar Energy 169, 362-373. 
Chemisana, D., Rosell, J.I., Riverola, A., Lamnatou, Chr., 2016. Experimental performance of a Fresnel-transmission PVT concentrator for building-façade integration. Renew. Energy 85, 564-572.

Chen, F., Yin, H., 2016. Fabrication and laboratory-based performance testing of a building-integrated photovoltaic-thermal roofing panel. Appl. Energy 177, 271-284.

Chen, Y., Galal, K., Athienitis, A.K., 2010. Modeling, design and thermal performance of a BIPV/T system thermally coupled with a ventilated concrete slab in a low energy solar house: Part 2, ventilated concrete slab. Solar Energy 84, 1908-1919.

Chialastri, A., Isaacson, M., 2017. Performance and optimization of a BIPV/T solar air collector for building fenestration applications. Energy Build. 150, 200-210.

Chow, T.T., Hand, J.W., Strachan, P.A., 2003. Building-integrated photovoltaic and thermal applications in a subtropical hotel building. Appl. Thermal Eng. 23, 2035-2049.

Chow, T.T., He, W., Chan, A.L.S., Fong, K.F., Lin, Z., Ji, J., 2008. Computer modeling and experimental validation of a building-integrated photovoltaic and water heating system. Appl. Thermal Eng. 28, 1356-1364.

Chow, T.T., Ji, J., 2012. Environmental Life-Cycle Analysis of Hybrid Solar Photovoltaic/Thermal Systems for Use in Hong Kong. Hindawi Publishing Corporation. I. J. Photoenergy, Volume 2012, Article ID 101968, 9 pages, doi:10.1155/2012/101968

Corbin, C.D., Zhai, Z.J., 2010. Experimental and numerical investigation on thermal and electrical performance of a building integrated photovoltaic-thermal collector system. Energy Build. 42, 76-82.

Crawford, R.H., Treloar, G.J., Fuller, R.J., Bazilian, M., 2006. Life-cycle energy analysis of building integrated photovoltaic systems (BiPVs) with heat recovery unit. Renew. Sust. Energy Rev. 10, 559-575.

Cristofari, C., Notton, G., Canaletti, J.L., 2009. Thermal behavior of a copolymer PV/Th solar system in low flow rate conditions. Solar Energy 83, 1123-1138.

Debbarma, M., Sudhakar, K., Baredar, P., 2017. Thermal modeling, exergy analysis, performance of BIPV and BIPVT: A review. Renew. Sustain. Energy Rev. 73, 12761288.

Delisle, V., Kummert, M., 2016. Cost-benefit analysis of integrating BIPV-T air systems into energy-efficient homes. Solar Energy 136, 385-400.

Deo, A., Mishra, G.K., Tiwari, G.N., 2017. A thermal periodic theory and experimental validation of building integrated semi-transparent photovoltaic thermal (BiSPVT) system. Solar Energy 155, 1021-1032.

ecoinvent, http://www.ecoinvent.org/database/database.html 
Gautam, K.R., Andresen, G.B., 2017. Performance comparison of building-integrated combined photovoltaic thermal solar collectors (BiPVT) with other building-integrated solar technologies. Solar Energy 155, 93-102.

Gholampour, M., Ameri, M., 2016. Energy and exergy analyses of Photovoltaic/Thermal flat transpired collectors: Experimental and theoretical study. Appl. Energy 164, 837-856.

Gupta, N., Tiwari, A., Tiwari, G.N., 2017. A thermal model of hybrid cooling systems for building integrated semitransparent photovoltaic thermal system. Solar Energy 153, 486-498.

Gupta, N., Tiwari, G.N., 2018. Effect of water flow on building integrated semitransparent photovoltaic thermal system with heat capacity. Sustain. Cit. Soc. 39, 708-718.

Hailu, G., Dash, P., Fung, A.S., 2015. Performance Evaluation of an Air Source Heat Pump Coupled with a Building-Integrated Photovoltaic/Thermal (BIPV/T) System under Cold Climatic Conditions. Energy Procedia 78, 1913 - 1918.

Hsu, D.D., O’Donoughue, P., Fthenakis, V., Heath, G.A., Kim, H.C., Sawyer, P., et al. 2012. Life Cycle Greenhouse Gas Emissions of Crystalline Silicon Photovoltaic Electricity Generation, Journal of Industrial Ecology, Volume 16, Number S1, Pages S122-S135.

Hu, J., Chen, W., Zhao, B., Song, H., 2014. Experimental studies on summer performance and feasibility of a BIPV/T ethylene tetrafluoroethylene (ETFE) cushion structure system. Energy Build. 69, 394-406.

Ibrahim, A., Fudholi, A., Sopian, K., Othman, M.Y., Ruslan, M.H., 2014. Efficiencies and improvement potential of building integrated photovoltaic thermal (BIPVT) system. Energy Convers. Manage. 77, 527-534.

ILCD, 2010. European Commission - Joint Research Centre - Institute for Environment and Sustainability: International Reference Life Cycle Data System (ILCD) Handbook General guide for Life Cycle Assessment - Detailed guidance. First edition March 2010. EUR 24708 EN. Luxembourg. Publications Office of the European Union.

ISO 14040:2006. Environmental management - Life cycle assessment - Principles and framework.

ISO 14044:2006. Environmental management - Life cycle assessment - Requirements and guidelines.

Jouhara, H., Milko, J., Danielewicz, J., Sayegh, M.A., Szulgowska-Zgrzywa, M., Ramos, J.B., et al., 2016. The performance of a novel flat heat pipe based thermal and $\mathrm{PV} / \mathrm{T}$ (photovoltaic and thermal systems) solar collector that can be used as an energyactive building envelope material. Energy 108, 148-154. 
Kamthania, D., Tiwari, G.N., 2014. Energy metrics analysis of semi-transparent hybrid PVT double pass facade considering various silicon and non-silicon based PV module Hyphen is accepted. Solar Energy 100, 124-140.

Khaki, M., Shahsavar, A., Khanmohammadi, S., Salmanzadeh, M., 2017. Energy and exergy analysis and multi-objective optimization of an air based building integrated photovoltaic/thermal (BIPV/T) system. Solar Energy 158, 380-395.

Kim, J.-H., Kim, J.-T., 2012. A simulation study of air-type building-integrated photovoltaic-thermal system. Energy Procedia 30, 1016 - 1024.

Krauter, S., Guido Araújo, R., Schroer, S., Hanitsch, R., Salhi, M.J., Triebel, C., et al., 1999. Combined photovoltaic and solar thermal systems for facade integration and building insulation. Solar Energy 67 (4-6), 239-248.

Lamnatou, Chr., Baig, H., Chemisana, D., Mallick, T.K., 2017. Dielectric-based 3D building-integrated concentrating photovoltaic modules: An environmental life-cycle assessment. Energy Build. 138, 514-525.

Lamnatou, Chr., Chemisana, D., 2017. Photovoltaic/thermal (PVT) systems: A review with emphasis on environmental issues. Renew. Energy 105, 270-287.

Lamnatou, Chr., Moreno, A., Chemisana, D., Reitsma, F., Clariá, F., 2018a. Ethylene tetrafluoroethylene (ETFE) material: Critical issues and applications with emphasis on buildings. Renew. Sustain. Energy Rev. 82, 2186-2201.

Lamnatou, Chr., Motte, F., Notton, G., Chemisana, D., Cristofari, C., 2018b. Cumulative energy demand and global warming potential of a building-integrated solar thermal system with/without phase change material. J. Environ. Manage. 212, 301-310.

Lamnatou, Chr., Motte, F., Notton, G., Chemisana, D., Cristofari, C., 2018c. Buildingintegrated solar thermal system with/without phase change material: Life cycle assessment based on ReCiPe, USEtox and Ecological footprint. J. Clean. Prod. 193, 672-683.

Li, S., Joe, J., Hu, J., Karava, P., 2015. System identification and model-predictive control of office buildings with integrated photovoltaic-thermal collectors, radiant floor heating and active thermal storage. Solar Energy 113, 139-157.

Li, S., Karava, P., Currie, S., Lin, W.E., Savory, E., 2014. Energy modeling of photovoltaic thermal systems with corrugated unglazed transpired solar collectors - Part 1: Model development and validation. Solar Energy 102, 282-296.

Lin, W., Ma, Z., Cooper, P., Sohel, M.I., Yang, L., 2016. Thermal performance investigation and optimization of buildings with integrated phase change materials and solar photovoltaic thermal collectors. Energy Build. 116, 562-573.

Luo, Y., Zhang, L., Liu, Z., Wang, Y., Meng, F., Wu, J., 2016. Thermal performance evaluation of an active building integrated photovoltaic thermoelectric wall system. Appl. Energy 177, 25-39. 
Martins, A.C., Chapuis, V., Sculati-Meillaud, F., Virtuani, A., Ballif, C. (2018), Light and durable: Composite structures for building-integrated photovoltaic modules, Prog Photovolt Res Appl. 26, 718-729.

Meneghelli, A., 2018. Whole-building embodied carbon of a North American LEEDcertified library: Sensitivity analysis of the environmental impact of buildings materials. Build. Environ. 134, 230-241.

Methodology of ecoinvent 3, https://www.ecoinvent.org/support/faqs/methodology-ofecoinvent-3/what-do-the-shortcuts-such-as-ch-rer-row-and-glo-mean.html

Moreno, A., Riverola, A., Chemisana, D., 2018. Energetic simulation of a dielectric photovoltaic-thermal concentrator. Solar Energy 169, 374-385.

Motte, F., Notton, G., Lamnatou, Chr., Cristofari, C., Chemisana, D., 2017. Numerical study of PCM integration impact on overall performances of a highly buildingintegrated solar collector. Renew. Energy. Article in press.

Nayak, S., Tiwari, G.N., 2008. Energy and exergy analysis of photovoltaic/thermal integrated with a solar greenhouse. Energy Build. 40, 2015-2021.

Nemati, O., Candanedo Ibarra, L.M., Fung, A.S., 2016. Review of computer models of air-based, curtainwall-integrated PV/T collectors. Renew. Sustain. Energy Rev. 63, $102-117$.

Oliveira, A.C., 2016. A novel solar façade concept for energy polygeneration in buildings. Int. J. Low-Carbon Tech. 11(4), 506-510.

Olmez, G.M., Dilek, F.B., Karanfil, T., Yetis, U., 2016. The environmental impacts of iron and steel industry: a life cycle assessment study. J. Clean. Prod. 130, 195-201.

Owusu, P.A., Asumadu-Sarkodie, S., 2016. A review of renewable energy sources, sustainability issues and climate change mitigation, Cogent Engineering (2016), 3: 1167990.

Piratheepan, M., Anderson, T.N., 2017. Performance of a building integrated photovoltaic/thermal concentrator for facade applications. Solar Energy 153, 562-573.

PRé, various authors, SimaPro Database Manual, Methods Library, Report version 2.6, May 2014.

Rajoria, C.S., Agrawal, S., Dash, A.K., Tiwari, G.N., Sodha, M.S., 2016. A newer approach on cash flow diagram to investigate the effect of energy payback time and earned carbon credits on life cycle cost of different photovoltaic thermal array systems. Solar Energy 124, 254-267.

Roeleveld, D., Hailu, G., Fung, A.S., Naylor, D., Yang, T., Athienitis, A.K., 2015. Validation of Computational Fluid Dynamics (CFD) Model of a Building Integrated Photovoltaic/Thermal (BIPV/T) System. Energy Procedia 78, 1901 - 1906. 
Rounis, E.D., Athienitis, A.K., Stathopoulos, T., 2016. Multiple-inlet Building Integrated Photovoltaic/Thermal system modelling under varying wind and temperature conditions. Solar Energy 139, 157-170.

Saadon, S., Gaillard, L., Giroux-Julien, S., Ménézo, C., 2016. Simulation study of a naturally-ventilated building integrated photovoltaic/thermal (BIPV/T) envelope. Renew. Energy 87, 517-531.

Shahsavar, A., Rajabi, Y., 2018. Exergoeconomic and enviroeconomic study of an air based building integrated photovoltaic/thermal (BIPV/T) system. Energy 144, 877-886.

SimaPro, https://simapro.com/

Smyth, M., 2013. (WO2014020328) A SOLAR WATER HEATER. https://patentscope.wipo.int/search/en/detail.jsf?docId=WO2014020328

Smyth, M., Pugsley, A., Hanna, G., Zacharopoulos, A., Mondol, J., Besheer, A., et al., 2018. Experimental performance characterisation of a Hybrid Photovoltaic/Solar Thermal Façade module compared to a flat Integrated Collector Storage Solar Water Heater module. Renew. Energy. Article in press.

Sun, Y., 2014. Life cycle assessment of a novel building-integrated photovoltaicthermal (BIPVT) system. MSc thesis. Department of Earth and Environmental Engineering. Columbia University. January 2014. New York.

Tiwari, S., Tiwari, G.N., 2017. Thermal analysis of photovoltaic thermal integrated greenhouse system (PVTIGS) for heating of slurry in potable biogas plant: An experimental study. Solar Energy 155, 203-211.

Tripanagnostopoulos, Y., Souliotis, M., Battisti, R., Corrado, A., 2006. Performance, Cost and Life-cycle Assessment Study of Hybrid PVT/AIR Solar Systems. Prog. Photovolt: Res. Appl. 14, 65-76.

Tripanagnostopoulos, Y., Souliotis, M., Battisti, R., Corrado, A., 2005. Energy, Cost and LCA Results of PV and Hybrid PV/T Solar Systems. Prog. Photovolt: Res. Appl. $13,235-250$.

Tripathy, M., Joshi, H., Panda, S.K., 2017. Energy payback time and life-cycle cost analysis of building integrated photovoltaic thermal system influenced by adverse effect of shadow. Appl. Energy 208, 376-389.

Üçtuğ, F.G., Azapagic, A., 2018. Environmental impacts of small-scale hybrid energy systems: Coupling solar photovoltaics and lithium-ion batteries. Sci. Tot. Environ. 643, 1579-1589.

Ulloa, C., Nuñez, J.M., Lin, C., Rey, G., 2018. AHP-based design method of a lightweight, portable and flexible air-based PV-T module for UAV shelter hangars. Renew. Energy 123, 767-780. 
Vuong, E., Kamel, R.S., Fung, A.S., 2015. Modelling and Simulation of BIPV/T in EnergyPlus and TRNSYS. Energy Procedia 78, 1883-1888.

Wang, Y., Ke, S., Liu, F., Li, J., Pei, G., 2017. Performance of a building-integrated photovoltaic/thermal system under frame shadows. Energy Build. 134, 71-79.

Wang, Z., Qiu, F., Yang, W., Zhao, X., Mei, S., 2016. Experimental investigation of the thermal and electrical performance of the heat pipe BIPV/T system with metal wires. Appl. Energy 170, 314-323.

Xiang, Y., Gan, G., 2015. Optimization of building-integrated photovoltaic thermal air system combined with thermal storage. Int. J. Low-Carbon Tech. 10, 146-156.

Xue, J., Liu, G., Brown, M.T., Casazza, M. 2018. Trash or treasure? Prospects for full aluminum chain in China based on the recycling options. J. Clean. Prod. 193, 217-227.

Yin, H.M., Yang, D.J., Kelly, G., Garant, J., 2013. Design and performance of a novel building integrated PV/thermal system for energy efficiency of buildings. Solar Energy 87, 184-195. 


\section{Graphical abstract}
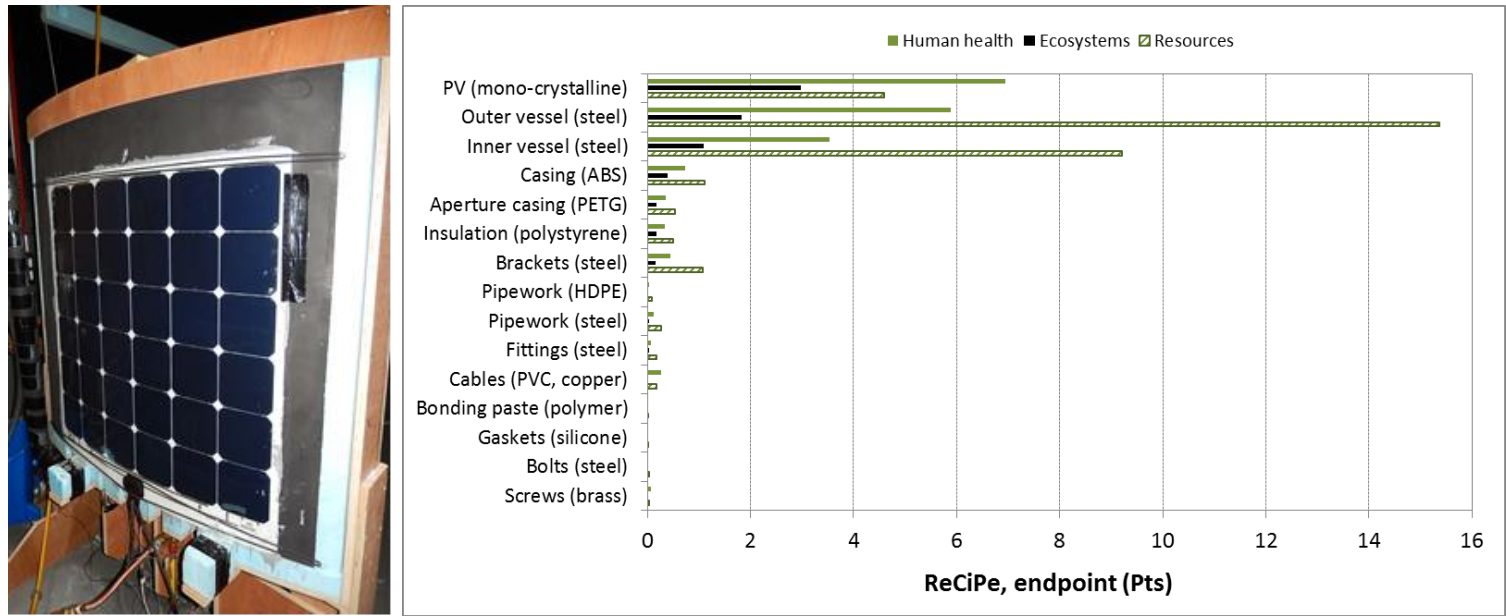


\section{Highlights}

- Environmental assessment of a Building-Integrated Photovoltaic/Thermal prototype

- Methods: ReCiPe, etc.; Issues: Global Warming Potential (GWP), Human toxicity, etc.

- Based on all methods: Cells, vessels show the highest impacts (primary materials)

- Impact per $\mathrm{m}^{2}$ of thermal absorber (primary materials): $4.92 \mathrm{GJ}_{\text {prim }}, 0.34 \mathrm{t} \mathrm{CO}_{2 . \mathrm{eq}}$

- Steel recycling offers a considerable impact reduction ranging from $47 \%$ to $85 \%$ 